Document downloaded from:

http://hdl.handle.net/10251/140868

This paper must be cited as:

Negreiros, AMP.; Sales, R.; Rodrigues A.P.M.S.; León Santana, M.; Armengol Fortí, J. (19$0)$. Prevalent weeds collected from cucurbit fields in Northeastern Brazil reveal new species diversity in the genus Monosporascus. Annals of Applied Biology. 174(3):349-363. https://doi.org/10.1111/aab.12493

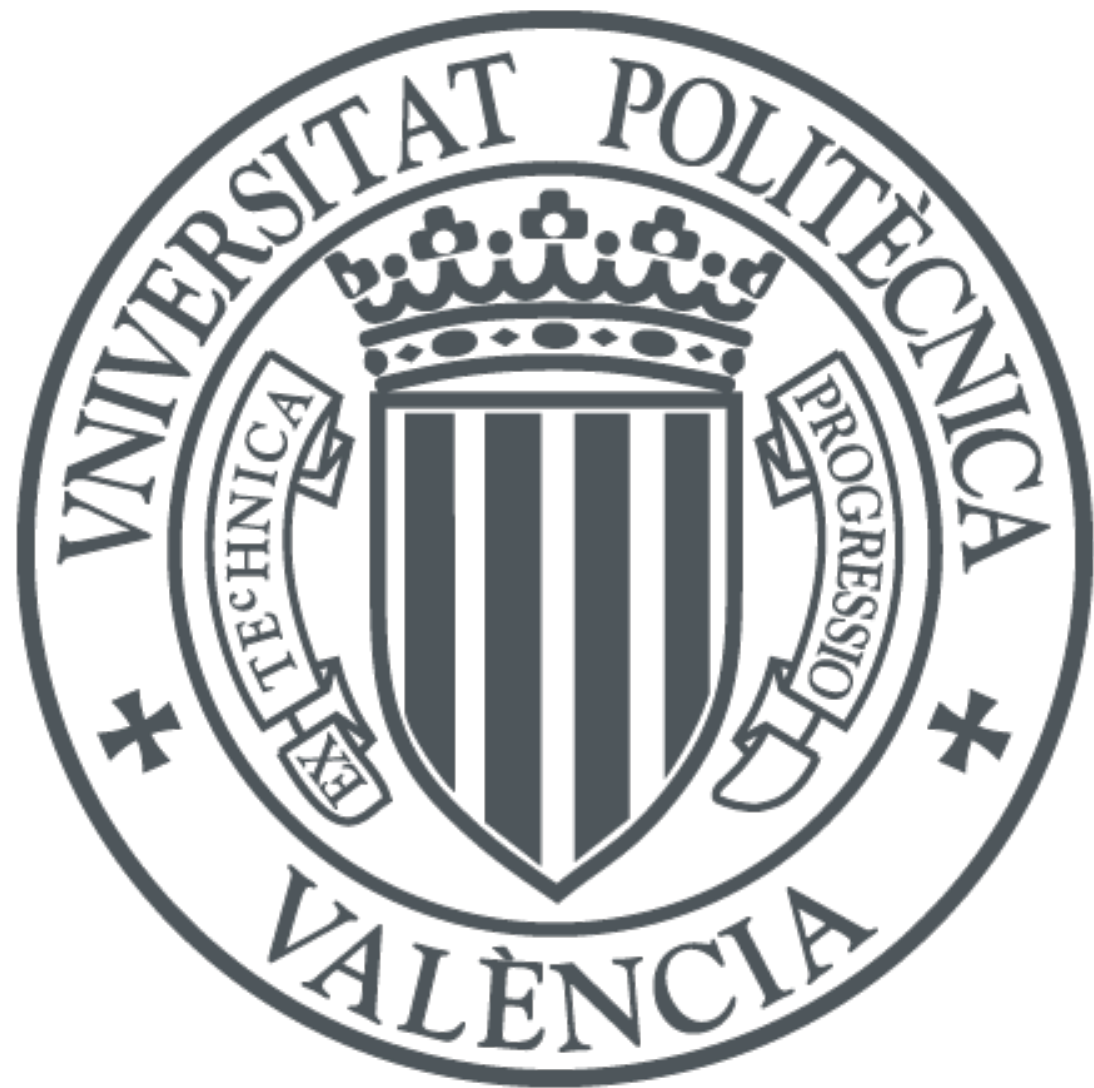

The final publication is available at

https://doi.org/10.1111/aab.12493

Copyright Blackwell Publishing

Additional Information

"This is the peer reviewed version of the following article: Negreiros, AMP, Júnior, RS, Rodrigues, APMS, León, M, Armengol, J. Prevalent weeds collected from cucurbit fields in Northeastern Brazil reveal new species diversity in the genus Monosporascus. Ann Appl Biol. 2019; 174: 349 363. https://doi.org/10.1111/aab.12493, which has been published in final form at https://doi.org/10.1111/aab.12493. This article may be used for non-commercial purposes in accordance with Wiley Terms and Conditions for Self-Archiving." 


\title{
Prevalent weeds collected from cucurbit fields in Northeastern Brazil reveal new species diversity in the genus Monosporascus
}

A.M.P. Negreiros ${ }^{1}$, R. Sales Júnior ${ }^{1}$, A.P.M.S. Rodrigues ${ }^{1}$, M. León ${ }^{2} \&$ J. Armengol ${ }^{2}$

1 Centro de Ciências Agrárias, Universidade Federal Rural do Semi-Árido, Mossoró, RN, Brazil

2 Instituto Agroforestal Mediterráneo, Universitat Politècnica de València, Valencia, Spain

Correspondence

Dr R. Sales Júnior, Centro de Ciências Agrárias, Universidade Federal Rural do SemiÁrido, Mossoró, RN 59625-900, Brazil. Email: ruisales@ufersa.edu.br

Keywords

Ascomycetes, Boerhavia diffusa, Monosporascus, soilborne pathogens, Trianthema portulacastrum

\begin{abstract}
Fungal species belonging to the ascomycete genus Monosporascus have no known asexual morph and the ascocarp is a globose perithecium where asci develop, containing from 1 to 6 spherical ascospores, depending on the species. Monosporascus cannonballus is the most well-known species of the genus, and an important root pathogen associated with the vine decline of melon and watermelon crops worldwide. The aim of the present study was to characterize a collection of 35 Monosporascus-like isolates recovered from
\end{abstract}


roots of two weed species prevalent in cucurbit growing fields in Northeastern Brazil: Boerhavia diffusa and Trianthema portulacastrum. These isolates were identified based on DNA sequences of the Internal Transcribed Spacer regions (ITS) of the nuclear rDNA, part of the translation elongation factor gene $(t e f-1 \alpha)$, part of the $\beta$-tubulin gene $(t u b)$, part of the nuclear small subunit rDNA (SSU), and part of the large subunit rDNA (LSU). Five Monosporascus species, namely M. brasiliensis, M. caatinguensis, M. mossoroensis, M. nordestinus and M. semiaridus, are newly described. Monosporascus brasiliensis, $M$. nordestinus and M. semiaridus were isolated from both weed species, while $M$. caatinguensis only from $T$. portulacastrum and M. mossoroensis only from B. diffusa. The present study confirms that Monosporascus spp. can colonize roots of very diverse hosts, even without causing noticeable disease symptoms, and reveals that the diversity of species in the genus Monosporascus is potentially greater than previously expected.

\section{Introduction}

The ascomycete genus Monosporascus Pollack \& Uecker 1974, and the type species $M$. cannonballus Pollack \& Uecker 1974, were described from a specimen obtained from necrotic melon roots in Arizona (USA) (Troutman \& Matejka, 1970; Pollack \& Uecker, 1974). To date, five species belonging to this genus have been reported worldwide: $M$.

adenantherae (S. D. \& C. Ramesh) A. Pande (Patil \& Ramesh, 1987), M. cannonballus Pollack \& Uecker (Pollack \& Uecker, 1974), M. eutypoides (Petrak) von Arx (Petrak \& Ahmad, 1954; Ben Salem et al., 2013), M. ibericus Collado, Ant. González, Stchigel, Guarro \& Peláez (Collado et al., 2002), and M. monosporus (Malloch \& Cain) D. Hawksw. \& Ciccar (Malloch \& Cain, 1971). However, M. adenantherae and M. 
monosporus do not have a reference isolate deposited in culture collections or gene sequences available on genetic databases.

Species belonging to the genus Monosporascus share some common features: they are homothallic, there is no asexual morph known and the ascocarp is a globose perithecium where asci develop, containing from 1 to 6 spherical, smooth, reticulate or slightly granulose, brown to black ascospores, depending on the species (Collado et al., 2002; Cohen et al., 2012). All Monosporascus species are soilborne and, in general, they seem to be adapted to hot, arid or semiarid climates, with saline and alkaline soils (Cohen et al., 2012).

Monosporascus cannonballus is the most well-known species of the genus, and an important root pathogen associated with the vine decline of melon (Cucumis melo L.) and watermelon [Citrullus lanatus (Thunb.) Matsum \& Nakai] crops worldwide (Martyn \& Miller, 1996; Bruton, 1998; Cohen et al., 2012). To date, this pathogen has been reported in cucurbit growing areas of 22 countries (Cohen et al., 2012; Al-Mawaali et al., 2013; Yan et al., 2016, Markakis et al., 2018), as the causal agent of the disease named "Monosporascus root rot and vine decline" (MRRVD) (Martyn \& Miller, 1996). In Brazil, M. cannonballus was reported in 2004 and 2010, affecting the roots of melon and watermelon plants, respectively (Sales Júnior et al., 2004; 2010), being the only Monosporascus species found in this country.

Currently, melon is the second most exported fresh fruit in Brazil, worth US \$ 162.9 million (Anuário, 2018), with the main producing States being Rio Grande do Norte - RN $(13,183$ ha) and Ceará - CE (3,242 ha), which together represent $76 \%$ of the melon produced by the country (IBGE, 2018). Brazil occupies the 11 th position $(596,430 \mathrm{t})$ among the world's largest producers of this cucurbit (FAO, 2018). Brazil is the fourth largest watermelon producer in the world, with a production of 2.090 million $\mathrm{t}$ in 94.555 
ha (IBGE, 2018), with the main producing States being Rio Grande do Sul - RS $(15,835$ ha) and Bahia - Ba (14,209 ha). However, the watermelons produced in these States are marketed mainly internally (Anuário, 2018).

The production of melon and watermelon in the RN and CE States, located in Northeastern Brazil, is characterized by the use of high yield inputs such as hybrid seeds, high frequency irrigation and mulching, being the cultivation carried out in monoculture with two or more repeated cycles in the same land each growing season (Figuerêdo et al., 2017). According to Bruton et al. (1998), these cultural practices may be associated with an increased incidence of MRRVD in cucurbits cultivation. Beltrán et al. (2005), studying the population dynamics of $M$. cannonballus ascospores in a field where the monoculture of melon was practiced, concluded that this practice increased the incidence of the disease in the field, as well as the number of ascospores in soil. In Brazil, Medeiros et al. (2006) detected the presence of $M$. cannonballus in areas of virgin forest of the Caatinga Biome in the Brazilian Northeast by counting ascospores in soil samples, confirming that this fungus is a natural inhabitant of the soil. It should be noted that these natural areas in the States of the RN and CE are the same that when deforested are used for cultivating melon and watermelon crops.

In addition to root pathogens, weeds also interfere with agricultural production, as they compete directly with the main crop for water, light and nutrients, as well as release allelopathic substances that inhibit plant development and serve as host of microorganisms (Soares et al., 2010; Sales Júnior et al., 2012; Lemessa \& Wakjira, 2014). Recently, Rodrigues (2017) and Sales Júnior et al. (2019) evaluated the occurrence of weeds as alternative hosts of root phytopathogenic fungi in cucurbit production areas in the Brazilian states of RN and CE, reporting 13 weed species as hosts of fungal root pathogens associated with vine decline of melon and watermelon such as Macrophomina 
phaseolina (Tassi) Goid. and Rhizoctonia solani Kühn. Of these 13 species, two were reported as hosts of M. cannonballus: Boerhavia diffusa L. and Trianthema portulacastrum L. Consequently, additional extensive surveys of these weed species, prevalent in cucurbit growing fields in the RN and CE States in Brazil, were carried out, from which a collection of 35 Monosporascus-like isolates were obtained. Thus, the objective of this work was to determine the identity of these isolates by means of phenotypical characterization (morphology and temperature growth), and DNA sequence analyses of the Internal Transcribed Spacer regions (ITS) of the nuclear rDNA, part of the translation elongation factor gene $(t e f-1 \alpha)$, part of the $\beta$-tubulin gene $(t u b)$, part of the nuclear small subunit rDNA (SSU), and part of the large subunit rDNA (LSU).

\section{Materials and Methods}

\section{Sampling and isolation}

Apparently healthy plants of $T$. portulacastrum and B. diffusa were collected from three cucurbits production farms, two located in RN State and one located in CE State (Northeastern Brazil). In each farm three different fields (2 ha each) were surveyed and approximately 25 plants of each species were collected in each field and examined carefully.

Roots were washed under running tap water, surface disinfested for $1 \mathrm{~min}$ in a $1.5 \%$ sodium hypochlorite solution and washed twice with sterile distilled water. Small pieces of slightly discolored tissues were placed onto potato dextrose agar (PDA) Petri dishes (Merck KGaA, Darmstadt, Germany) amended with $0.5 \mathrm{~g} \mathrm{~L}^{-1}$ of streptomycin sulphate (Sigma-Aldrich, St. Louis, MO, USA) (PDAS). Plates were incubated for 3 to 5 days at $25^{\circ} \mathrm{C}$ in darkness. 
Thirty-five Monosporascus-like isolates, 18 from $T$. portulacastrum and 17 from $B$. diffusa (Table 1) were transferred to PDA, hyphal-tipped, and stored in 15\% glycerol solution at $-80^{\circ} \mathrm{C}$ into $1.5 \mathrm{ml}$ cryovials at the fungal collection of Phytopathogenic Fungi "Prof. Maria Menezes" (CMM) at the Universidade Federal Rural de Pernambuco (Recife, Pernambuco, Brazil).

\section{DNA extraction, PCR amplification and sequencing}

Total fungal DNA was extracted using the E.Z.N.A. Plant DNA Kit (Omega Bio-tek, USA), following the manufacturer's short protocol instructions with some modifications in the samples preparation step. Briefly, lysis buffer P1 (650 $\mu 1)$ was added to the mycelia in a 2-ml screw-capped conical tubes (Thermo Scientific) containing four metal $2.38 \mathrm{~mm}$ beads (Qiagen) and two tungsten carbide $3 \mathrm{~mm}$ beads (Qiagen) and homogenized twice at $5 \mathrm{~m} / \mathrm{s}$ for $20 \mathrm{~s}$ using FastPrep-24TM $5 \mathrm{G}$ (MP Biomedicals, Santa Ana, CA, USA).

Five loci were amplified and sequenced: the Internal Transcribed Spacer regions (ITS) of the nuclear rDNA amplified with the primers ITS1-F (Gardes \& Bruns, 1993) and ITS4 (White et al., 1990), part of the translation elongation factor gene (tef-1 $\alpha)$ using primers EF1-688F (forward) and EF1-1251R (reverse) (Alves et al., 2008), part of the $\beta$-tubulin gene $(t u b)$ using primers BtCadF and BtCadR (Travadon et al., 2015), part of the nuclear small subunit rDNA (SSU) using primers NS1 and NS4 (White et al., 1990), and part of the large subunit rDNA (LSU) using primers LROR and LR5 (Vilgalys \& Hester, 1990). Amplification by polymerase chain reaction (PCR) was performed using Horse-Power ${ }^{\mathrm{TM}}$ Taq DNA Polymerase (Canvax Biotech SL, Córdoba, Spain), according to the manufacturer's instructions on a Peltier Thermal Cycler-200 (MJ Research). The thermal cycle consisted of an initial step of $3 \mathrm{~min}$ at $94^{\circ} \mathrm{C}$, followed by 35 cycles of denaturation 
at $94^{\circ} \mathrm{C}$ for $30 \mathrm{~s}$, annealing at $55^{\circ} \mathrm{C}$ for $30 \mathrm{~s}$, and elongation at $72^{\circ} \mathrm{C}$ for $45 \mathrm{~s}$. A final extension was performed at $72^{\circ} \mathrm{C}$ for $10 \mathrm{~min}$. PCR products were analyzed by $1 \%$ agarose gel electrophoresis and were sequenced by Macrogen Inc. (Madrid, Spain) using both PCR primers. Each consensus sequence was assembled using Sequencher software 5.0 (Gene Codes Corp., Ann Arbor, Michigan).

New sequences were deposited in GenBank and were listed in Table 1 with additional sequences of M. cannonballus (CMM2386, CMM2429, MC0603 and MC1103), $M$. eutypoides (MT45), M. ibericus (CBS 110550), Arecophila (A.) bambusae (HKUCC4794), Seynesia erumpens (SMH 1291), Arthrinium (Ar.) hysterinum (ICMP 6889), Ar. phaeospermum (HKUCC 3395), Apiospora (Ap.) setosa (ICMP 4207), Diatrype palmicola (MFLUCC 11-0018 and MFLUCC 11-0020) and Eutypa lata (CBS 208.87) obtained from GenBank. The alignments were deposited in TreeBASE (http://purl.org/phylo/treebase/phylows/study/TB2:S22884).

\section{Phylogenetic analyses}

For each of the five loci (LSU, SSU, ITS, tefl- $\alpha$ and $t u b$ ), the DNA sequences from this study, together with those retrieved from Genbank (Table 1) were aligned using the ClustalW algorithm (Thompson et al., 1994) contained within MEGA7 software package (Kumar et al., 2016). The alignments were inspected and corrected manually. Incomplete portions at either end of the alignments were excluded prior to analyses.

The Genealogical Concordance Phylogenetic Species Recognition concept (GCPSR, Taylor et al., 2000) was the approach used to identify phylogenetic species based on the existence of statistically supported phylogenetic clades that are present in the majority (at 
least two of three) of single-locus trees and that are not contradicted by any other singlegene tree(s) determined by the same method.

To determine whether the DNA sequence datasets were congruent, a partition homogeneity test (Farris et al., 1994) of all possible combinations was conducted in PAUP 4.0b10 (Swofford, 2003). Two concatenated datasets were built in Sequence Matrix v.1.8 (Vaidya et al., 2011). First dataset, LSU/SSU matrix, was used to infer the position and assess the phylogenetic relationships of the genus Monosporascus inside the family Diatrypaceae and the order Xylariales, and to test the monophyly of the genus. For this purpose, some representative species of these family and order were selected. $A$. bambusae (HKUCC4794), S. erumpens (SMH 1291), Ar. hysterinum (ICMP 6889), Ar. phaeospermum (HKUCC 3395), Ap. setosa (ICMP 4207) were chosen as outgroups based on Maharachchikumbura et al. (2016). Second dataset, ITS/tef1- $\alpha / t u b$ matrix, was used to infer the relative position of species inside the Monosporascus genus. In this analysis no outgroup was inserted and the trees generated were midpoint rooted.

Phylogenetic analyses for each locus and concatenated datasets were based on Bayesian inference (BI), Maximum Likelihood (ML) and Maximum Parsimony (MP). Bayesian analyses were performed using MrBayes v 3.2 (Ronquist et al., 2012) on the CIPRES Science Gateway V 3.3 (Miller et al., 2010). The best-fitting model of nucleotide evolution for each partition was determined by MrModeltest 2.3 (Nylander, 2004) using the Akaike Information Criterion (AIC). Four simultaneous analysis were run for 100 millions generations, sampling every 1000, with four Markov Chain Monte Carlo (MCMC) chains. The first $25 \%$ of saved trees were discarded and posterior probabilities determined from the remaining trees. The ML analyses were done with the tool RAxML - HPC2 on XSEDE (Stamatakis, 2014) implemented on CIPRES Science Gateway V 3.3 (Miller et al., 2010). ML tree searches were performed under the GTRGAMMA model 
with 1000 pseudoreplicates. The other parameters were used as default settings. Phylogenetic analyses consisting of MP were performed in MEGA 7 (Kumar et al., 2016) with the Subtree-Pruning-Regrafting (SPR) algorithm, where gaps were treated as missing data. The robustness of the topology was evaluated by 1000 bootstrap replications (Felsenstein, 1985). Measures for the maximum parsimony as tree length (TL), consistency index (CI), retention index (RI) and rescaled consistency index (RC) were also calculate.

Monosporascus spp. are homothallic ascomycetes, thus all progeny from an ascocarp will be genetically identical because they are derived from a single haploid genome, meiosis does not change the multilocus genotype (Kohn, 1995). Nevertheless, for determine the recombination level within phylogenetically closely related species using a five-locus concatenated dataset, a Pairwise homoplasy index (PHI) test (Philippe \& Bryant 2006) was performed in SplitsTree4 (Huson \& Bryant 2006) (http://ab.inf.unituebingen.de/software/splitstree4/).

\section{Taxonomy}

Agar plugs (6-mm-diam) were taken from the edge of active PDA cultures and transferred onto the centre of 9-cm-diam Petri dishes containing the following culture media: PDA; 2\% tap water agar supplemented with sterile melon (C. melo) root fragments; potato carrot agar (PCA) (grated potato $20 \mathrm{~g}$, grated carrot $20 \mathrm{~g}$, agar $20 \mathrm{~g}$ and tap water 1 1); sugar beet agar (grated sugar beet $25 \mathrm{~g}$, agar $20 \mathrm{~g}$ and tap water 1 1); and V-8 juice agar (V-8 juice $200 \mathrm{ml}, \mathrm{CaCO}_{3} 2 \mathrm{~g}$, agar $15 \mathrm{~g}$ and distilled water $800 \mathrm{ml}$ ). Plates were then incubated during two months at 25 and $30^{\circ} \mathrm{C}$ in darkness to induce sporulation. Cultures were examined periodically for the development of ascomata and ascospores. Colony 
colours and pigment production were rated only on PDA after 30 days of incubation according to Rayner (1970). Morphological characteristics were examined by mounting single perithecia in $100 \%$ lactic acid v/v and observed using a Zeiss Axio Scope A.1 microscope. The diameter of 50 perithecia and 50 ascospores, and the length and width of 25 asci per isolate were measured using the imaging device Zeiss AxioVision LE. Photos were captured using a Zeiss AxioCam MRm digital camera from images recorded with the 40x objective. Descriptions, nomenclature and illustrations of taxonomic novelties were deposited in MycoBank (MB826726, MB826728, MB826729, MB826730 and MB826731) (Pollack \& Uecker, 1974, Ben Salem et al., 2013, Collado et al., 2002, Crous et al., 2004).

The effect of temperature on mycelial growth of selected isolates (Table 2) was measured on PDA. For this purpose, agar plugs (6-mm-diam) obtained from the growing edge of colonies were transferred to the center of PDA plates which were incubated at 10, 15, 20, $25,30,35$ or $40^{\circ} \mathrm{C}$ in darkness. Four replicates for each isolate and temperature combination were used. The diameter of each colony was measured perpendicularly in two directions when the colony reached at least two thirds of the plate diameter, and the mean growth rate was calculated in $\mathrm{mm} /$ day. Analyses of variance (ANOVA) were conducted with temperature experiments data to analyse potential trial-by-treatment interactions. ANOVA indicated that the data for the two repetitions were similar for each variable $(\mathrm{P}>0.05)$, thus data from both repeats of the experiments were combined. For each isolate, average growth rates at each temperature were adjusted to a regression curve using Statgraphics Plus 5.1 (Manugistics Inc., Rockville, MD), and the best polynomial model was chosen based on parameter significance $(\mathrm{P}<0.05)$ and coefficient of determination (R2) to estimate the optimum growth temperature. 


\section{Results}

\section{Sequence alignment and phylogenetic analysis}

The first approximation to the identification of the 35 isolates, putatively belonging to Monosporascus genus, was based on the BLAST analysis of their ITS sequence, showing the highest identities between 92-96\% with some accessions of Monosporascus species. Subsequently, Monosporascus sequence matrices (LSU, SSU, ITS, tef-1 $\alpha$, and $t u b$ ) were built. The combined datasets of LSU/SSU and ITS/tef-1 $1 \alpha /$ tub were used to infer the phylogenetic relationships among known and new Monosporascus species.

The results of the partition homogeneity test $(\mathrm{P}>0.05)$ for all possible combination of the two (LSU/SSU) and three (ITS/tef-1 $\alpha /$ tub) loci indicated that the datasets were congruent. Phylogenies resulting from the individual locus (Figures S1, S2, S3, S4, S5, S6, S7, S8, S9, S10, S11, S12, S13, S14 and S15) also were compared visually, and no differences could be detected for the LSU/SSU and ITS/tef-1 $\alpha / t u b$, and therefore the sequences of these two and three regions were combined, respectively. In ITS, tef-1 $\alpha$ and tub datasets, the terminal clades representing species were the same for all gene regions, supporting the congruency of the different phylogenies. The topology of the trees identified by ML analysis of both concatenated datasets were identical to those obtained by the BI and MP analyses (Figures S16, S17, S18 and S19), therefore only the ML trees are presented with ML and MP bootstrap support values and BI posterior probability scores at the nodes.

\section{Monosporascus within the family Diatrypaceae}


The combined alignment of LSU and SSU used for ML, BI and MP analyses contained 49 taxa, including outgroups, and 1635 base pairs in length (681 base pairs for LSU and 954 for SSU). Sequences of ex-type isolates of M. cannonballus, M. eutypoides, $M$. ibericus, A. bambusae, S. erumpens, Ar. hysterinum, Ar. phaeospermum, Ap. setosa, D. palmicola and E. lata were obtained from GenBank and included in the analysis together with the sequences of isolates generated in this study (Table 1).

Maximum likelihood analysis resulted in a single best ML tree with $-\operatorname{lnL}=-3779.31365$. For the MP analysis 1464 characters were constant, 120 parsimony-informative and 51 were variable and parsimony-uninformative, yielding 10 equally most parsimonious trees $(\mathrm{TL}=255 ; \mathrm{CI}=0.760 ; \mathrm{RI}=0.897 ; \mathrm{RC}=0.681)$. In the $\mathrm{BI}$ analysis, the LSU partition had 107 unique site patterns and the SSU partition had 66. The analysis read a total of 40,004 trees, sampling 30,004 of them.

The phylogenies inferred from individual genes (data not shown) and the two-loci phylogeny (Fig. 1) showed that our isolates belong to the genus Monosporascus with the genera Diatrype and Eutypa as sister groups inside the family Diatrypaceae belonging to the order Xylariales. The genus Monosporascus appeared as a well supported monophyletic clade that is divided into two sub-clades: one includes $M$. eutypoides, $M$. cannonballus and four new Monosporascus species (M. mossoroensis, M. nordestinus, M. semiaridus and M. brasiliensis), and the other contains M. ibericus and another new Monosporascus species (M. caatinguensis). Pairwise sequence percentage identity among Monosporascus species at the LSU and SSU regions is shown in Table 3.

\section{Phylogenetic relationships within the genus Monosporascus}


The three-loci (ITS/tef-1 $\alpha /$ tub) dataset included 41 sequences (Table 1) from which 35 were of our studied isolates and six of the three Monosporascus species with sequences and cultures available: M. cannonballus $(\mathrm{n}=4)$, M. eutypoides $(\mathrm{n}=1)$ and M. ibericus $(\mathrm{n}$ =1) (Fig. 2). The alignment, including gaps, consisted of 1864 characters (519 bp for ITS, 647 for tef- $1 \alpha$ and 686 for tub), of which 1460 were constant, 320 parsimonyinformative, and 84 variable and parsimony-uninformative. Parsimony analysis yield 10 most parsimonious trees $(\mathrm{TL}=489 ; \mathrm{CI}=0.878 ; \mathrm{RI}=0.981$ and $\mathrm{RC}=0.861)$. The $\mathrm{ML}$ analysis resulted in a single best tree with $-\operatorname{lnL}=-5107.97577$. In the BI analysis, the ITS/tef-1 $\alpha /$ tub partitions had 103/129/98 unique site patterns respectively, and the analysis read a total of 40,004 trees, sampling 30,004 of them.

The phylogenetic analysis resolved the dataset into eight clades. Three of them corresponded to previously described Monosporascus species, but none of our isolates clustered with them. The other five clades, with $100 \%$ bootstrap support for MP and ML and 1 of BI posterior probability, corresponded to the new species of Monosporascus (M. mossoroensis, M. nordestinus, M. semiaridus, M. brasiliensis and M. caatinguensis). These eight clades maintained the same relationship between them presented in LSUSSU phylogeny.

The M. mossoroensis clade, formed by ten isolates, and the M. nordestinus clade, represented by three isolates, are both phylogeneticaly close to $M$. cannonballus and $M$. eutypoides (Fig. 2). The M. semiaridus clade with nine isolates and the M. brasiliensis clade, with eight isolates, formed a group closely related between them. The $M$. caatinguensis clade, with five isolates, is closely related to M. ibericus.

The isolates of the M. semiaridus clade were divided in two sub-clades by one base transition in ITS region sequences. Moreover, the alignments of tef- $1 \alpha$ and $t u b$ of the $M$. 
brasiliensis clade showed the presence of intraspecific variabilities with four indels and one transition, respectively, resulting also in two sub-clades.

Pairwise sequence percentage identity among Monosporascus species at the ITS, tef- $1 \alpha$ and $t u b$ regions is shown in Table 3.

The PHI test revealed that there was no significant genetic recombination within this dataset (mean $=0.051, P=0.259)$.

\section{Taxonomy}

Five new species of Monosporascus are described based on the phylogenetic analysis and morphological characters (Fig. 3, Fig. 4 and Fig. 5).

Monosporascus brasiliensis A. Negreiros, M. León, J. Armengol \& R. Sales Júnior, sp. nov. MycoBank MB 826726 (Fig. 3).

Etymology: Name refers to Brazil, where the fungus was isolated.

Diagnosis: Cultures sterile. One hundred and sixty-three polymorphisms can distinguish M. brasiliensis from its closest phylogenetic species $M$. semiaridus: 51 (31 indels) in ITS locus; 60 (14 indels) in tef-1 $\alpha$ locus; 45 (4 indels) in tub locus; 6 (2 indels) in LSU locus; and 1 in SSU locus.

Typus: Brazil: Assú, Rio Grande do Norte on Trianthema portulacastrum (complete roots), 2014, R. Sales Júnior (holotype; CMM 4839 - ex-type culture).

Culture characteristics: colonies on PDA showed mycelium cottony with average density (Fig. 3). Surface buff without zonation and reverse ochreous to amber. Optimum growth temperature $32.1^{\circ} \mathrm{C}$. Growth rate of colonies on PDA at 30 and $35^{\circ} \mathrm{C}$ was 89 and $96 \mathrm{~mm}$ per day, respectively. No growth was observed at 10 and $45^{\circ} \mathrm{C}$. 
Host and distribution: Boerhavia diffusa and Trianthema portulacastrum (roots) (Brazil, Rio Grande do Norte).

Notes: Isolates of M. brasiliensis could not be induced to sporulate on any of the media used in this study, nor on sterilized fragments of melon roots placed on tap water agar, even after repeated attempts. Monosporascus brasiliensis is closely related to $M$. semiaridus based on phylogenetic inference.

Monosporascus caatinguensis A. Negreiros, M. León, J. Armengol \& R. Sales Júnior, sp. nov. MycoBank MB 826728 (Fig. 3).

Etymology: Name refers to Caatinga Biome, where the fungus was isolated. Deforested Caatinga areas are used for intensive cucurbits cultivation.

Diagnosis: Cultures sterile. Two hundred and twenty four polymorphisms can distinguish M. caatinguensis from its closest phylogenetic species M. ibericus: 60 (29 indels) in ITS locus; 88 (16 indels) in tef- $1 \alpha$ locus; 59 (13 indels) in tub locus; 12 ( 1 indels) in LSU locus; and 5 in SSU locus.

Typus: Brazil: Limoeiro do Norte, Ceará on Boerhavia diffusa (complete roots), 2014, R. Sales Júnior (holotype; CMM 4833 - ex-type culture).

Culture characteristics: colonies on PDA showed mycelium flat with low density (Fig. 3). Surface honey and reverse amber. Optimum growth temperature $30.7^{\circ} \mathrm{C}$. Growth rate of colonies on PDA at 30 and $35^{\circ} \mathrm{C}$ was 53 and $45 \mathrm{~mm}$ per day, respectively. No growth was observed at 10 and $45^{\circ} \mathrm{C}$.

Host and distribution: Boerhavia diffusa (roots) (Brazil, Ceará).

Notes: Isolates of $M$. caatinguensis could not be induced to sporulate on any of the media used in this study, nor on sterilized fragments of melon roots placed on tap water agar, 
even after repeated attempts. Monosporascus caatinguensis is closely related to $M$. ibericus based on phylogenetic inference.

Monosporascus mossoroensis A. Negreiros, M. León, J. Armengol \& R. Sales Júnior, sp. nov. MycoBank MB 826729 (Fig. 3).

Etymology: Name refers to Mossoró locality in Rio Grande do Norte State, where the fungus was isolated.

Diagnosis: Cultures sterile. Twenty polymorphisms can distinguish M. mossoroensis from its closest phylogenetic species M. nordestinus: 8 (2 indels) in ITS locus; 7 in tef$1 \alpha$ locus; 4 in $t u b$ locus; and 1 in LSU locus.

Typus: Brazil: Mossoró, Rio Grande do Norte on Trianthema portulacastrum (complete roots), 2014, R. Sales Júnior (holotype; CMM 4857 - ex-type culture).

Culture characteristics: colonies on PDA showed mycelium cottony with low density (Fig. 3). Surface honey and reverse honey to umber. Optimum growth temperature $31.8^{\circ} \mathrm{C}$. Growth rate of colonies on PDA at 30 and $35^{\circ} \mathrm{C}$ was 86 and $74 \mathrm{~mm}$ per day, respectively. No growth was observed at 10 and $45^{\circ} \mathrm{C}$.

Host and distribution: Trianthema portulacastrum (roots) (Brazil, Rio Grande do Norte). Notes: Isolates of M. mossoroensis could not be induced to sporulate on any of the media used in this study, nor on sterilized fragments of melon roots placed on tap water agar, even after repeated attempts. Monosporascus mossoroensis is closely related to $M$. nordestinus based on phylogenetic inference.

Monosporascus nordestinus A. Negreiros, M. León, J. Armengol \& R. Sales Júnior, sp. nov. MycoBank MB 826730 (Fig. 4). 
Etymology: Name refers to the Brazilian North East Region, where the fungus was isolated.

Diagnosis: Asexual morph not seen. Twenty polymorphisms can distinguish $M$. nordestinus from its closest phylogenetic species M. mossoroensis: 8 (2 indels) in ITS locus; 7 in tef-1 $\alpha$ locus; 4 in tub locus; and 1 in LSU locus.

Typus: Brazil: Mossoró, Rio Grande do Norte on Trianthema portulacastrum (complete roots), 2014, R. Sales Júnior (holotype; CMM 4846 - ex-type culture).

Ascomata superficial to semi-immersed, scattered, globose to hemi-spherical, nonostiolate, dark brown, (452-) 549 (-668) $\mu \mathrm{m}$ diam. Asci 1- to 3-spored, fasciculate, clavate to subcylindrical, thick-walled, stipitate, rounded at the apex and evanescent: one-spored $(76.0-) 85.0(-114.9) \times(40.5-) 46.0(-52.1) \mu \mathrm{m}$, two-spored (95.4-) $100.4(-137.4) \times(39.4-$ ) $45.9(-50.8) \mu \mathrm{m}$, and three-spored (105.2-) $120.4(-150.4) \times(39.0-) 42.5(-44.7) \mu \mathrm{m}$ diam. Ascospores one-celled, globose, thick-walled, hyaline when young, becoming dark brown to black when mature, smooth, (35.6-) 42.9 (-48.6) $\mu \mathrm{m}$ diam, without germ pores. Paraphyses numerous, filiform, hyaline. Asexual morph unknown.

Culture characteristics: colonies on PDA showed mycelium cottony with density average to strong (Fig. 4). Surface buff without zonation and reverse luteous to sienna. Optimum growth temperature $32.4^{\circ} \mathrm{C}$. Growth rate of colonies on PDA at 30 and $35^{\circ} \mathrm{C}$ were 92 and $96 \mathrm{~mm}$ per day, respectively. No growth was observed at 10 and $45^{\circ} \mathrm{C}$. Ascomata were produced on PDA, PCA, sugar beet agar and V-8 juice agar. Ascospore germination was not observed on any of the culture media used and at any of the incubation temperatures tested.

Host and distribution: Boerhavia diffusa and Trianthema portulacastrum (roots) (Brazil, Rio Grande do Norte). 
Notes: M. nordestinus is closely related to M. mossoroensis based on phylogenetic inference. The morphology of this species is close to M. eutypoides, which also presents 1 to 3 ascospores per ascus, but M. nordestinus can be distinguished by its higher optimum growth rate temperature, $32.4^{\circ} \mathrm{C}$ (this study), when compared to M. eutypoides: 29.38 to $29.49^{\circ} \mathrm{C}$ (Ben Salem et al., 2013).

Monosporascus semiaridus A. Negreiros, M. León, J. Armengol \& R. Sales Júnior, sp. nov. MycoBank MB 826731 (Fig. 5).

Etymology: Name refers to the name refers to semiarid Brazilian region, where the fungus was isolated.

Diagnosis: Asexual morph not seen. One hundred and sixty-three polymorphisms can distinguish M. semiaridus from its closest phylogenetic species M. brasiliensis: 51 (31 indels) in ITS locus; 60 (14 indels) in tef-1 $\alpha$ locus; 45 (4 indels) in tub locus; 6 (2 indels) in LSU locus; and 1 in SSU locus.

Typus: Brazil: Limoeiro do Norte, Ceará on Trianthema portulacastrum (complete roots), 2014, R. Sales Júnior (holotype; CMM 4830 - ex-type culture).

Ascomata superficial to semi-immersed, scattered, globose to hemi-spherical, nonostiolate, dark brown, (426-) 546 (-724) $\mu \mathrm{m}$ diam. Asci 1-spored, fasciculate, clavate to subcylindrical, thick-walled, stipitate, rounded at the apex and evanescent, (50.2-) 67.1 (77.0) $\times(32.4-) 43.7(-44.5) \mu \mathrm{m}$ diam. Ascospores one-celled, globose, thick-walled, hyaline when young, becoming dark brown to black when mature, smooth, (34.4-) 43.2 (-52.3) $\mu \mathrm{m}$ diam, without germ pores. Paraphyses numerous, filiform, hyaline. Anamorph unknown.

Culture characteristics: colonies on PDA showed mycelium cottony with average density (Fig. 5). Surface buff to honey without zonation and reverse sepia. Optimum growth 
temperature $31.3^{\circ} \mathrm{C}$. Growth rate of colonies on PDA at 30 and $35^{\circ} \mathrm{C}$ was $96 \mathrm{~mm}$ per day at both temperatures. No growth was observed at 10 and $45^{\circ} \mathrm{C}$. Ascomata were produced only on sugar beet agar and V-8 juice agar. Ascospore germination was not observed on any of the culture media used and at any of the incubation temperatures tested. Host and distribution: Boerhavia diffusa and Trianthema portulacastrum (roots) (Brazil, Ceará and Rio Grande do Norte).

Notes: M. semiaridus is closely related to $M$. brasiliensis based on phylogenetic inference. The morphology of this species is close to M. cannonballus, which also presents one ascospore, rarely two, per ascus, but $M$. semiaridus can be distinguished by its slightly shorter asci, 50.2 to $77.0 \mu \mathrm{m}$ (this study), when compared to M. cannonballus: 56 to $90 \mu \mathrm{m}$ (Sivanesan, 1991a).

\section{Discussion}

Five species of Monosporascus, namely M. brasiliensis, M. caatinguensis, $M$. mossoroensis, M. nordestinus and M. semiaridus are here described, all originating from the semi-arid region in Northeastern Brazil, and none of them represent previously described taxa. These fungi were found associated with roots of two native weed species, B. diffusa and T. portulacastrum collected from cucurbit growing fields. Monosporascus brasiliensis, M. nordestinus and M. semiaridus were isolated from both weed species, while $M$. caatinguensis only from $T$. portulacastrum and M. mossoroensis only from $B$. diffusa. The semi-arid region of Northeastern Brazil is characterized by sandy-alkaline soils and high temperatures during all the year, like other regions where Monosporascus spp. have been reported (Cohen et al., 2012). Moreover, the optimum growth temperatures of the new Monosporascus spp. were over $30^{\circ} \mathrm{C}$. Thus, the environmental 
conditions required by them are similar to those described for the other species of the genus.

The results of the phylogenetic analyses of the 35 isolates supported the position and evaluation of the phylogenetic relationships of the genus Monosporascus inside the family Diatrypaceae and the order Xylariales, as suggested by previous molecular studies (Collado et al., 2002; Maharachchikumbura et al., 2015; 2016), and not to Sordariales as firstly indicated by Hawksworth \& Ciccarone (1978). The use of the LSU/SSU loci allowed us to corroborate the phylogenetic placement of the isolates of this study at the taxonomic levels of family and order with strong support (Raja et al., 2017). These results confirm that the genera Monosporascus, Diatrype and Eutypa are closely related, proving that they are sister groups (Maharachchikumbura et al., 2016).

All Monosporascus isolates obtained in this study were phylogenetically related to $M$. cannonballus, M. eutypoides and M. ibericus, the only species of the genus Monosporascus from which nucleotide sequences or living cultures are currently available, and they formed distinct clades. Monosporascus species were monophyletic based on the three-gene tree (ITS/tef-1 $\alpha / t u b)$ with strong support. The dataset of the three loci showed a close relationship between $M$. mossoroensis and M. nordestinus, and both with M. cannonballus (Pollack \& Uecker, 1974) and M. eutypoides (von Arx, 1975). Monosporascus semiaridus and $M$. brasiliensis were closely related, while $M$. caatinguensis formed a well-supported monophyletic sister clade with M. ibericus (Collado et al., 2002).

In our study DNA sequence data have been very useful to determine the identity of Monosporascus spp., because it is very difficult to distinguish species within this genus based only on morphology (Cohen et al., 2012). The number of ascospores per ascus and ascospores germinability had been traditionally used as the main morphological features 
for speciation in the genus Monosporascus (Cohen et al., 2012; Ben Salem et al., 2013), while ascospore size has been considered inappropriate, because it may be variable for a single Monosporascus strain depending on the growth conditions and the maturity of the spores (Hawksworth \& Ciccarone, 1978; Martyn \& Miller, 1996).

Collado et al. (2002), compared the morphology of M. ibericus with that of the three species M. cannonballus, M. eutypoides and M. monosporus based on literature descriptions. These authors indicated that $M$. ibericus was the most distinctive species of the genus, exhibiting a frequent higher number (5 to 6 ) of ascospores per ascus, whilst $M$. eutypoides, the other multisporous species of the genus, has only up to three ascospores (usually two) (Petrak \& Ahmad, 1954), as recently confirmed by Ben Salem et al. (2013). Monosporascus cannonballus presents one spore per ascus (rarely two) and $M$. monosporus only one (Malloch \& Cain, 1971; Pollack \& Uecker, 1974; Sivanesan, 1991a, b). Regarding ascospores germination, the ascospores of M. ibericus do not germinate in axenic culture (Collado et al., 2002), while Sivanesan (1991b) indicated that the ascospores of $M$. eutypoides produce multiple germ tubes readily at temperatures of 30$40^{\circ} \mathrm{C}$. First descriptions of $M$. cannonballus indicated that its ascospores did not germinate in vitro (Pollack \& Uecker, 1974; Hawksworth \& Ciccarone, 1978), but subsequent studies were able to obtain ascospore germination by using thermal treatments at $45^{\circ} \mathrm{C}$ (Martyn et al., 1992) or in the rhizosphere of melon plants growing in nonautoclaved field soil (Stanghellini et al., 2000). This soil methodology was used later by Ben Salem et al. (2013), who also obtained germination of M. eutypoides ascospores. Our study adds five new species to the genus Monosporascus and, although we had been able to obtain the sexual morph for two of them, M. nordestinus and M. semiaridus, our results corroborate that, even for these two species, the use of morphological characters alone is insufficient for species delimitation in this genus. For the other three new species, 
M. brasiliensis, M. caatinguensis and M. mossoroensis, it was not possible to obtain asexual or sexual spores in any of the culture media used. Therefore, the use of DNA sequences analyses, either ITS, tef-1 $\alpha$ or tub, is highly recommended for Monosporascus spp. identification.

Currently, only the species $M$. cannonballus and M. eutypoides are considered important plant pathogens, both associated with MRRVD disease of cucurbits. For instance, to date in Brazil, only M. cannonballus has been reported from watermelon and melon roots (Sales Júnior et al., 2004; 2010), but T. portulacastrum and B. diffusa were already reported as hosts for this pathogen in cucurbit growing areas of Northeastern Brazil (Rodrigues, 2017). In fact, other non-cucurbit plant species have also been reported as hosts of Monosporascus spp., these being: Adenanthera pavonina L. (Patil \& Ramesh, 1987), for M. adenantherae; Medicago sativa L. (Pollack \& Uecker, 1974), Trifolium pratense L. (Sivanesan, 1991a), M. sativa, Zea mays L., Beta vulgaris L., Sorghum bicolor (L.) Moench, T. aestivum L. and Phaseolus vulgaris L. (Mertely et al., 1993), Lepidium lasiocarpum Nutt. (Stanghellini et al., 1996), and S. bicolor, Solanum lycopersicum L. and Z. mays (Sales Júnior et al., 2018), for M. cannonballus; Achyranthes aspera L. (Sivanesan et al., 1974; Hawksworth \& Ciccarone, 1978), Triticum sp. (Hawksworth \& Ciccarone, 1978), and Sesamum indicum L. (Sivanesan, 1991b), for M. eutypoides; Plantago crassifolia Forssk. and Atriplex portulacoides L. (Collado et al., 2002), for M. ibericus; and Iris sp. (Malloch \& Cain, 1971) for M. monosporus. Overall, this information is an indication that Monosporascus spp. may be able to colonize roots of very diverse hosts, even without causing noticeable disease symptoms. In fact, MRRVD is a complex disease and other microorganisms have been reported to play an important role on the occurrence of the disease (Stanghellini and Misaghi, 2011; Aleandri et al., 2017). 
Boerhavia diffusa and T. portulacastrum plants collected in our surveys were apparently healthy and only slightly root discolorations were observed, from which the new Monosporascus species were isolated. In the case of M. cannonballus and M. eutypoides, this could also partially explain the rapid emergence of MRRVD worldwide when noncultivated areas are dedicated to cucurbits cultivation as suggested by Cohen et al. (2012), as it is the case of the cucurbit growing areas of Northeastern Brazil. Moreover, the exposure of melon and watermelon roots to Monosporascus spp. by colonized weeds could also enhance the potential emergence of the new species described here as cucurbit pathogens.

Our findings reveal that the diversity of species in the genus Monosporascus is potentially greater than previously expected. Consequently, additional extensive surveys of the roots of weed and crop species should be conducted in other cucurbit growing areas of the world to better understand their role as alternative hosts of Monosporascus spp., including pathogenicity tests of the new species detected, in order to determine their host range.

\section{Acknowledgements}

This research was supported by Coordenação de Aperfeiçoamento de Pessoal de Nível Superior (CAPES) and by Conselho Nacional de Desenvolvimento Científico e Tecnológico (CNPq).

\section{References}

Aleandri M. P., Martignoni D., Reda R., Alfaro-Fernández A., Font M.I., Armengol J., Chilosi G. (2017) Involvement of Olpidium bornovanus and O. virulentus in the occurrence of melon root and vine decline caused by Monosporascus cannonballus in central Italy. Journal of Plant Pathology, 99, 169-176. 
Al-Mawaali Q.S., Al-Sadi A.M., Al-Said F.A., Deadman M.L. (2013) Etiology, development and reaction of muskmelon to vine decline under arid conditions of Oman. Phytopathologia Mediterranea, 52, 457-465.

Alves A., Crous P.W., Correia A., Phillips A.J.L. (2008) Morphological and molecular data reveal cryptic speciation in Lasiodiplodia theobromae. Fungal Diversity, 28, 1-13. Anuário - Anuário Brasileiro da Fruticultura 2018. (2018), pp. 88. Santa Cruz do Sul, RS, Brazil: Editora Gazeta Santa Cruz.

Beltrán R., Vicent A., Sales Júnior R., García-Jiménez J., Armengol J. (2005) Population dynamics of Monosporascus cannonballus ascospores in marsh soils in eastern Spain. European Journal of Plant Patholology, 113, 357-365.

Ben Salem I., Correia K.C., Boughalleb N., Michereff S.J., León M., Abad-Campos P., García-Jiménez J., Armengol J. (2013) Monosporascus eutypoides, a cause of root rot and vine decline in Tunisia, and evidence that M. cannonballus and M. eutypoides are distinct species. Plant Disease, 97, 737-743.

Bruton B.D. (1998) Soilborne diseases in Cucurbitaceae: pathogen virulence and host resistance. In Proceedings of Cucurbitaceae '98. Evaluation and enhancement of cucurbit germplasm, pp. 143-166. Ed J.D. McCreight. Asilomar, CA: 01-04 December 1998. Alexandria, VA, USA: American Society for Horticultural Science Press.

Bruton B.D., Russo V.M., Garcia-Jiménez J., Miller M.E. (1998) Carbohydrate partitioning, cultural practices, and vine decline diseases of cucurbits. In Proceedings of Cucurbitaceae '98. Evaluation and enhancement of cucurbit germplasm, pp. 189-200. Ed J.D. McCreight. Asilomar, CA: 01-04 December 1998. Alexandria, VA, USA: American Society for Horticultural Science Press. 
Cohen R., Pivonia S., Crosby K.M., Martyn R.D. (2012) Advances in the biology and management of monosporascus vine decline and wilt of melons and other cucurbits. Horticultural Reviews, 39, 77-120.

Collado J., González A., Platas G., Stchigel A.M., Guarro J., Peláez F. (2002) Monosporascus ibericus sp. nov., an endophytic ascomycete from plants on saline soils, with observations on the position of the genus based on sequence analysis of the $18 \mathrm{~S}$ rDNA. Mycological Research, 106, 118-127.

Crous P.W., Gams W., Stalpers J.A., Robert V., Stegehuis G. (2004) MycoBank: an online initiative to launch mycology into the 21st century. Studies in Mycology, 50, 1922.

FAO (2018) - Food and Agriculture Organization of the United Nations. URL http://www.fao.org/faostat/en/\#home [accessed on September 2018].

Farris J.S., Kallersjo M., Kluge A.G., Bult C. (1994) Testing significance of incongruence. Cladistics, 10, 315-319.

Felsenstein J. (1985) Confidence limits on phylogenies: an approach using the bootstrap. Evolution, 39, 783-791.

Figuerêdo M.C.B., Gondim R.S., Aragão F.A.S. (2017) Produção de melão e mudanças climáticas: sistemas conservacionistas de cultivo para redução das pegadas de carbono e hídrica, pp. 302. Brasília, DF, Brazil: Empresa Brasileira de Pesquisa Agropecuária, EMBRAPA-CNPAT.

Gardes M., Bruns T.D. (1993) ITS primers with enhanced specifity for Basidiomycetes: application to identification of mycorrhizae and rusts. Molecular Ecology, 2, 113-118. Hawksworth D.L., Ciccarone A. (1978) Studies on a species of Monosporascus isolated from Triticum. Mycopathologia 66, 147-151 
Huson D.H., Bryant D. (2006) Application of phylogenetic networks in evolutionary studies. Molecular Biology and Evolution, 23, 254-267

IBGE. (2018) Instituto Brasileiro de Geografia e Estatística. URL https://sidra.ibge.gov.br/pesquisa/pam/tabelas [accessed on September 2018].

Kohn L.M. (1995) The clonal dynamic in wild and agricultural plant pathogen populations. Canadian Journal of Botany, 73, S1231-S1240

Kumar S., Stecher G., Tamura K. (2016) Molecular Evolutionary Genetics Analysis Version 7.0 for Bigger Datasets. Molecular Biology and Evolution, 33, 1870-1874.

Lemessa F., Wakjira M. (2014) Mechanisms of ecological weed management by cover cropping: a review. Journal of Biological Sciences, 14, 452-459.

Maharachchikumbura S.S.N., Hyde K.D., Jones E.B.G. (2015) Towards a natural classification and backbone tree for Sordariomycetes. Fungal Diversity, 72, 199-301.

Maharachchikumbura S.S.N., Hyde K.D., Jones E.B.G. (2016) Families of Sordariomycetes. Fungal Diversity, 79, 1-317.

Malloch D., Cain R.F. (1971) New cleistothecial Sordariaceae and a new family, Coniochaetaceae. Canadian Journal of Botany, 49, 869-880.

Markakis E.A., Trantas E.A., Lagogianni C.S., Mpalantinaki E., Pagoulatou M., Ververidis F.N., Goumas D.E. (2018) First report of root rot and vine decline of melon caused by Monosporascus cannonballus in Greece. Plant Disease, 102, 1036.

Martyn R.D., Miller M.E. (1996) Monosporascus root rot and vine decline: an emerging disease of melons worldwide. Plant Disease, 80, 716-725.

Martyn R.D., Mertely J.C., Miller M.E., Katsar C., Baasiri R. (1992) Morphology and germination of Monosporascus cannonballus ascospores. (Abstr.) Phytopathology, 82, 1115 . 
Medeiros E.V., Sales Júnior R., Michereff S.J., Barbosa M.R. (2006) Quantificação de ascósporos de Monosporascus cannonballus em solos não cultivados de Caatinga e em áreas de cultivo de melão do Rio Grande do Norte e Ceará. Fitopatologia Brasileira, 31, 500-504.

Mertely J.C., Martyn R.D., Miller M.E., Bruton B.D. (1993) An expanded host range for the muskmelon pathogen, Monosporascus cannonballus. Plant Disease, 77, 667-673. Miller M.A., Pfeiffer W., Schwartz T. (2010) Creating the CIPRES Science Gateway for inference of large phylogenetic trees. In Proceedings of the Gateway Computing Environments Workshop (GCE), New Orleans, LA, USA, pp. 1-8.

Nylander J.A. A. (2004) MrAIC.pl. Program distributed by the editor. Evolutionary Biology Centre, Uppsala University

Patil S.D., Ramesh C. (1987) Notes on some fungi of Pleosporaceae (Loculoascomycetes) from Maharashtra (India). Transactions of the Mycological Society of Japan, 28, 229236.

Petrak F., Ahmad S. 1954. Beiträge zur Pilzflora Pakistans. Sydowia, 8, 162-185.

Philippe H., Bryant D. (2006) A simple and robust statistical test for detecting the presence of recombination. Genetics, 172, 2665-2681

Pollack F.G., Uecker F.A. (1974) Monosporascus cannonballus an unusual ascomycete in cantaloupe roots. Mycologia, 66, 346-349

Raja H.A., Miller A.N., Pearce C.J., Oberlies N.H. (2017) Fungal identification using molecular tools: A primer for the natural products research community. Journal of Natural Products, 80, 756-770.

Rayner R.W. (1970) A Mycological Colour Chart, pp. 34. Kew, Surrey, England: Commonwealth Mycological Institute. 
Rodrigues A.P.M.S. (2017) Variabilidade de isolados de Monosporascus cannonballus oriundos de plantas daninhas em campos de produção de meloeiro. $\mathrm{PhD}$ Thesis. Universidade Federal Rural do Semi-Árido, Mossoró, Brazil.

Ronquist F., Teslenko M., van der Mark P., Ayres D.L., Darling A., Höhna S., Larget B., Liu L., Suchard M.A., Huelsenbeck J.P. (2012) MrBayes 3.2: efficient Bayesian phylogenetic inference and model choice across a large model space. Systematic Biology, 61, 539-542.

Sales Júnior R., Dias Balbino D.A., Paiva Negreiros A.M., Da Silva Barboza H., Valente de Medeiros E., Armengol J. (2018) Cotton, cowpea and sesame are alternative crops to cucurbits in soils naturally infested with Monosporascus cannonballus. Journal of Phytopathology, 166, 396-402.

Sales Júnior R., Nascimento I.J.B., Freitas L.S.R., Beltrán Armengol J., Vicent A., García-Jiménez J. (2004) First report of Monosporascus cannonballus on melon in Brazil. Plant Disease, 88, 84.

Sales Júnior R., Oliveira O.F., Medeiros E.V., Guimarães I.M., Correia K.C., Michereff S.J. (2012) Ervas daninhas como hospedeiras alternativas de patógenos causadores do colapso do meloeiro. Revista Ciência Agronômica, 43, 195-198.

Sales Júnior R., Rodrigues A.P.M.S., Negreiros A.M.P., Ambrósio M.M.Q., Barboza H. S., Beltrán R. (2019) Weeds as potential hosts for fungal root pathogens of watermelon. Revista Caatinga, 32, XX. (in press)

Sales Júnior R., Santana C.V.S., Nogueira D.R.S., Silva K.J.P., Guimarães I.M., Michereff S.J., Abad-Campos P., García-Jiménez J., Armengol J. (2010) First Report of Monosporascus cannonballus on Watermelon in Brazil. Plant Disease, 94, 278.

Sivanesan A. (1991a) IMI Descriptions of Fungi and Bacteria n. 1035. Monosporascus cannonballus. Mycopathologia, 114, 53-54. 
Sivanesan A. (1991b) IMI Descriptions of Fungi and Bacteria n. 1036. Monosporascus eutypoides. Mycopathologia, 114, 55-56.

Sivanesan A., Talde U. K., Tilak S.T. (1974) Bitrimonospora indica gen. et sp. nov., a new loculoascomycete from India. Transactions of The British Mycological Society, 63, 595-596.

Soares I.A.A., Freitas F.C.L., Negreiros M.Z., Freire G.M., Aroucha E.M.M., Grangeiro L.C., Lopes W.A.R., Dombroski J.L.D. (2010) Interferência das plantas daninhas sobre a produtividade e qualidade de cenoura. Planta Daninha, 28, 247-254.

Stamatakis A. (2014) - RAxML version 8: a tool for phylogenetic analysis and postanalysis of large phylogenies. Bioinformatics, 30, 1312-1313.

Stanghellini M.E., Kim D.H., Rasmussen S.L. (1996) Ascospores of Monosporascus cannonballus: Germination and distribution in cultivated and desert soils in Arizona. Phytopathology, 86, 509-514.

Stanghellini M.E., Kim D.H., Waugh M. (2000) Microbe-mediated germination of ascospores of Monosporascus cannonballus. Phytopathology, 90, 243-247.

Swofford D.L. (2003) PAUP*. Phylogenetic Analysis Using Parsimony (*and other methods). Version 4.0. Sinauer Associates, Sunderland, MA, USA.

Stanghellini M.E, Misaghi I.J. (2011). Olpidium bornovanus-mediated germination of ascospores of Monosporascus cannonballus: a host-specific rhizosphere interaction. Phytopathology, 101, 794-796.

Taylor J.W., Jacobson D.J., Kroken S., Kasuga T., Geiser D.M., Hibbett D.S., Fisher M.C. (2000) Phylogenetic species recognition and species concepts in fungi. Fungal Genetics and Biology, 31, 21-32. 
Thompson J.D., Higgins D.G., Gibson T.J. (1994) Clustal W: improving the sensitivity of progressive multiple sequence alignment through sequence weighting, positionspecific gap penalties and weight matrix choice. Nucleic Acids Research, 22, 4673-4680. Travadon R., Lawrence D., Rooney-Latham S., Gubler W.D., Wilcox W.F., Rolshausen P.E., Baumgartner K. (2015) Cadophora species associated with wood-decay of grapevine in North America. Fungal Biology, 119, 53-66.

Troutman J., Matejka J.C. (1970) Fungi associated with cantaloupe in Arizona. (Abstr.). Phytopathology, 60, 1317

Vaidya G., Lohman D.J., Meier R. (2011) SequenceMatrix: Concatenation software for the fast assembly of multi-gene datasets with character set and codon information. Cladistics, 27, 171-180.

Vilgalys R., Hester M. (1990) Rapid genetic identification and mapping of enzymatically amplified ribosomal DNA from several Cryptococcus species. Journal of Bacteriology, 172, 4238-4246.

von Arx J.A. (1975) On Thielavia angulata and some recently described Thielavia species. Kavaka, 3, 33-36.

White T.J., Bruns T.D., Lee S.B., Taylor J.W. (1990) Amplification and direct sequencing of fungal ribosomal RNA genes for phylogenetics. In PCR Protocols: A Guide to Methods and Applications. Volume 18, pp. 315-322. Eds M. Innis, D. Gelfand, J. Sninsky and T.J. White. Orlando, FL, USA: Academic Press.

Yan L.Y., Zang Q.Y., Huang Y.P., Wang Y.H. (2016) First report of root rot and vine decline of melon caused by Monosporascus cannonballus in Eastern Mainland China. Plant Disease, 100, 651. 
Table 1 Collection details and GenBank accession numbers of isolates included in this study

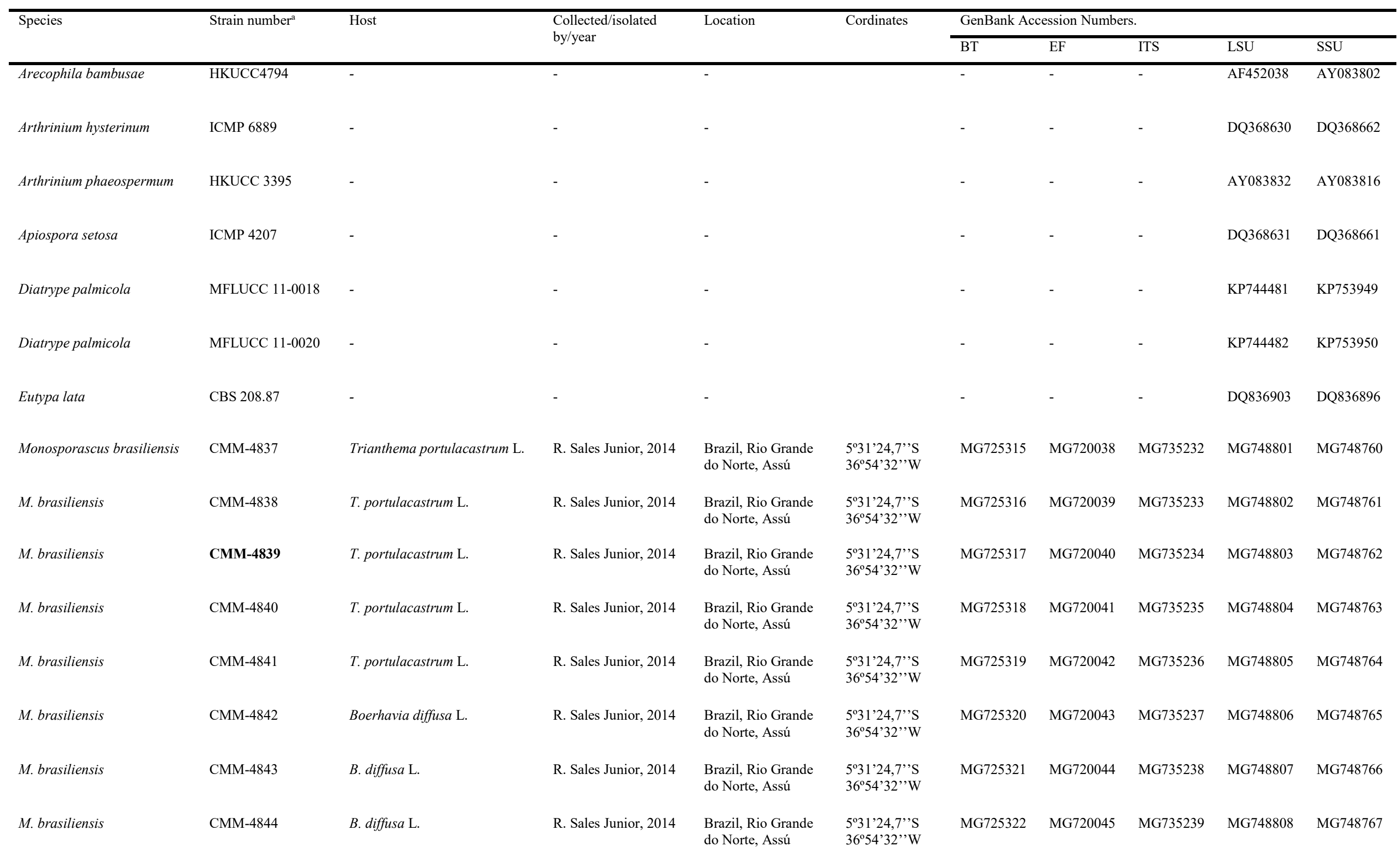




\begin{tabular}{|c|c|c|c|c|c|c|c|c|c|c|}
\hline \multirow[t]{2}{*}{ Species } & \multirow[t]{2}{*}{ Strain number ${ }^{a}$} & \multirow[t]{2}{*}{ Host } & \multirow{2}{*}{$\begin{array}{l}\text { Collected/isolated } \\
\text { by/year }\end{array}$} & \multirow[t]{2}{*}{ Location } & \multirow[t]{2}{*}{ Cordinates } & \multicolumn{5}{|c|}{ GenBank Accession Numbers. } \\
\hline & & & & & & BT & $\mathrm{EF}$ & ITS & LSU & SSU \\
\hline M. brasiliensis & CMM-4845 & B. diffusa L. & R. Sales Junior, 2014 & $\begin{array}{l}\text { Brazil, Rio Grande } \\
\text { do Norte, Assú }\end{array}$ & $\begin{array}{l}5^{\circ} 31^{\prime 2} 24,7^{\prime \prime \prime} \mathrm{S} \\
36^{\circ} 54^{\prime} 32^{\prime \prime} \mathrm{W}\end{array}$ & MG725323 & MG720046 & MG735240 & MG748809 & MG748768 \\
\hline M. caatinguensis & CMM-4832 & B. diffusa $\mathrm{L}$. & R. Sales Junior, 2014 & $\begin{array}{l}\text { Brazil, Ceará, } \\
\text { Limoeiro do Norte }\end{array}$ & $\begin{array}{l}5^{\circ} 11^{\prime} 06,11^{\prime \prime} \mathrm{S} \\
37^{\circ} 55^{\prime} 2,2,{ }^{\prime} \mathrm{W}\end{array}$ & MG725310 & MG720033 & MG735227 & MG748796 & MG748755 \\
\hline M. caatinguensis & CMM-4833 & B. diffusa $\mathrm{L}$. & R. Sales Junior, 2014 & $\begin{array}{l}\text { Brazil, Ceará, } \\
\text { Limoeiro do Norte }\end{array}$ & $\begin{array}{l}5^{\circ} 11^{\prime} 06,11^{\prime \prime} \mathrm{S} \\
37^{\circ} 55^{\prime} 2,2,{ }^{\prime} \mathrm{W}\end{array}$ & MG725311 & MG720034 & MG735228 & MG748797 & MG748756 \\
\hline M. caatinguensis & CMM-4834 & B. diffusa $\mathrm{L}$. & R. Sales Junior, 2014 & $\begin{array}{l}\text { Brazil, Ceará, } \\
\text { Limoeiro do Norte }\end{array}$ & $\begin{array}{l}5^{\circ} 11^{\prime} 06,11^{\prime \prime} \mathrm{S} \\
37^{\circ} 55^{\prime} 2,2, \mathrm{~W}\end{array}$ & MG725312 & MG720035 & MG735229 & MG748798 & MG74875 \\
\hline M. caatinguensis & CMM-4835 & B. diffusa $\mathrm{L}$. & R. Sales Junior, 2014 & $\begin{array}{l}\text { Brazil, Ceará, } \\
\text { Limoeiro do Norte }\end{array}$ & $\begin{array}{l}5^{\circ} 11^{\prime} 06,11^{\prime \prime} \mathrm{S} \\
37^{\circ} 55^{\prime} 2,2^{\prime \prime} \mathrm{W}\end{array}$ & MG725313 & MG720036 & MG735230 & MG748799 & MG748758 \\
\hline M. caatinguensis & CMM-4836 & B. diffusa $\mathrm{L}$. & R. Sales Junior, 2014 & $\begin{array}{l}\text { Brazil, Ceará, } \\
\text { Limoeiro do Norte }\end{array}$ & $\begin{array}{l}5^{\circ} 11^{\prime} 06,11^{\prime \prime} \mathrm{S} \\
37^{\circ} 55^{\prime} 2,2, \mathrm{~W}\end{array}$ & MG725314 & MG720037 & MG735231 & MG748800 & MG748759 \\
\hline M. cannonballus & CMM-2386 & Cucumis melo & - & $\begin{array}{l}\text { Brazil, Pau Branco, } \\
\text { Rio Grande do Norte }\end{array}$ & & JQ907303 & JQ907318 & JQ771917 & MG748825 & MG748784 \\
\hline M. cannonballus & CMM-2429 & C. melo & - & $\begin{array}{l}\text { Brazil, Rio Grande } \\
\text { do Norte, Mossoró }\end{array}$ & & JQ907311 & JQ907315 & JQ762366 & MG748826 & MG748785 \\
\hline M. cannonballus & MC0603 & C. melo & - & $\begin{array}{l}\text { Spain, Chilches, } \\
\text { Castellón }\end{array}$ & & JQ907307 & JQ907314 & JQ762364 & MG748824 & MG748783 \\
\hline M. cannonballus & MC1103 & C. melo & - & $\begin{array}{l}\text { Spain, Meliana, } \\
\text { Valencia }\end{array}$ & & JQ907302 & JQ907317 & JQ762369 & MG748823 & MG748782 \\
\hline M. eutypoides & MT45 & Citrullus lanatus & - & Tunisia, Sidi, Bouzid & & JQ973834 & JQ958959 & JQ958963 & MG748827 & MG748786 \\
\hline M. ibericus & CBS 110550 & - & - & $\begin{array}{l}\text { Spain, Los Alfaques, } \\
\text { Tarragona }\end{array}$ & & JQ973833 & JQ958958 & JQ973832 & MG748828 & MG748787 \\
\hline M. mossoroensis & CMM-4856 & T. portulacastrum L. & R. Sales Junior, 2014 & $\begin{array}{l}\text { Brazil, Rio Grande } \\
\text { do Norte, Mossoró }\end{array}$ & $\begin{array}{l}4^{\circ} 54^{\prime} 2^{\prime \prime} \mathrm{S} \\
37^{\circ} 24^{\prime} 17^{\prime}, \mathrm{W}\end{array}$ & MG725334 & MG720057 & MG735251 & MG748820 & MG748779 \\
\hline M. mossoroensis & CMM-4857 & T. portulacastrum L. & R. Sales Junior, 2014 & $\begin{array}{l}\text { Brazil, Rio Grande } \\
\text { do Norte, Mossoró }\end{array}$ & $\begin{array}{l}4^{\circ} 54^{\prime} 2^{\prime \prime} \mathrm{S} \\
37^{\circ} 24^{\prime} 17^{\prime \prime} \mathrm{W}\end{array}$ & MG725335 & MG720058 & MG735252 & MG748821 & MG748780 \\
\hline M. nordestinus & CMM-4846 & T. portulacastrum $\mathrm{L}$. & R. Sales Junior, 2014 & $\begin{array}{l}\text { Brazil, Rio Grande } \\
\text { do Norte, Mossoró }\end{array}$ & $\begin{array}{l}4^{\circ} 52^{\prime} 53,4^{\prime}{ }^{\prime} \mathrm{S} \\
37^{\circ} 26^{\prime} 20,25^{\prime}, \mathrm{W}\end{array}$ & MG725324 & MG720047 & MG735241 & MG748810 & MG748769 \\
\hline
\end{tabular}




\begin{tabular}{|c|c|c|c|c|c|c|c|c|c|c|}
\hline \multirow[t]{2}{*}{ Species } & \multirow[t]{2}{*}{ Strain number $^{\mathrm{a}}$} & \multirow[t]{2}{*}{ Host } & \multirow{2}{*}{$\begin{array}{l}\text { Collected/isolated } \\
\text { by/year }\end{array}$} & \multirow[t]{2}{*}{ Location } & \multirow[t]{2}{*}{ Cordinates } & \multicolumn{5}{|c|}{ GenBank Accession Numbers. } \\
\hline & & & & & & $\overline{B T}$ & $\overline{E F}$ & ITS & $\overline{\mathrm{LSU}}$ & $\overline{\mathrm{SSU}}$ \\
\hline M. nordestinus & CMM-4847 & T. portulacastrum L. & R. Sales Junior, 2014 & $\begin{array}{l}\text { Brazil, Rio Grande } \\
\text { do Norte, Mossoró }\end{array}$ & $\begin{array}{l}4^{0} 52^{\prime} 53,4^{\prime} \mathrm{S} \\
37^{\circ} 26^{\prime} 20,25^{\prime}, \mathrm{W}\end{array}$ & MG725325 & MG720048 & MG735242 & MG748811 & MG748770 \\
\hline M. nordestinus & CMM-4848 & T. portulacastrum $\mathrm{L}$. & R. Sales Junior, 2014 & $\begin{array}{l}\text { Brazil, Rio Grande } \\
\text { do Norte, Mossoró }\end{array}$ & $\begin{array}{l}4^{\circ} 52^{\prime} 53,4{ }^{\prime \prime} \mathrm{S} \\
37^{\circ} 26,20,25^{\prime}, \mathrm{W}\end{array}$ & MG725326 & MG720049 & MG735243 & MG748812 & MG748771 \\
\hline M. nordestinus & CMM-4849 & T. portulacastrum $\mathrm{L}$. & R. Sales Junior, 2014 & $\begin{array}{l}\text { Brazil, Rio Grande } \\
\text { do Norte, Mossoró }\end{array}$ & $\begin{array}{l}4^{\circ} 52^{\prime} 53,4, ' \mathrm{~S} \\
37^{\circ} 26{ }^{\prime} 20,25^{\prime}, \mathrm{W}\end{array}$ & MG725327 & MG720050 & MG735244 & MG748813 & MG748772 \\
\hline M. nordestinus & CMM-4850 & T. portulacastrum $\mathrm{L}$. & R. Sales Junior, 2014 & $\begin{array}{l}\text { Brazil, Rio Grande } \\
\text { do Norte, Mossoró }\end{array}$ & $\begin{array}{l}4^{\circ} 52^{\prime} 53,4{ }^{\prime \prime} \mathrm{S} \\
37^{\circ} 26,20,25{ }^{\prime}, \mathrm{W}\end{array}$ & MG725328 & MG720051 & MG735245 & MG748814 & MG748773 \\
\hline M. nordestinus & CMM-4851 & B. diffusa $\mathrm{L}$. & R. Sales Junior, 2014 & $\begin{array}{l}\text { Brazil, Rio Grande } \\
\text { do Norte, Mossoró }\end{array}$ & $\begin{array}{l}4^{\circ} 52^{\prime} 53,4^{\prime}{ }^{\prime} \mathrm{S} \\
37^{\circ} 266^{\prime} 20,25^{\prime}{ }^{\prime} \mathrm{W}\end{array}$ & MG725329 & MG720052 & MG735246 & MG748815 & MG748774 \\
\hline M. nordestinus & CMM-4852 & B. diffusa $\mathrm{L}$. & R. Sales Junior, 2014 & $\begin{array}{l}\text { Brazil, Rio Grande } \\
\text { do Norte, Mossoró }\end{array}$ & $\begin{array}{l}4^{\circ} 52^{\prime} 53,4{ }^{\prime \prime} \mathrm{S} \\
37^{\circ} 266^{\prime} 20,25^{\prime}, \mathrm{W}\end{array}$ & MG725330 & MG720053 & MG735247 & MG748816 & MG748775 \\
\hline M. nordestinus & CMM-4854 & B. diffusa $\mathrm{L}$. & R. Sales Junior, 2014 & $\begin{array}{l}\text { Brazil, Rio Grande } \\
\text { do Norte, Mossoró }\end{array}$ & $\begin{array}{l}4^{\circ} 52^{\prime} 53,4^{\prime \prime} \mathrm{S} \\
37^{\circ} 266^{\prime} 20,25^{\prime}, \mathrm{W}\end{array}$ & MG725332 & MG720055 & MG735249 & MG748818 & MG748777 \\
\hline M. nordestinus & CMM-4855 & B. diffusa $\mathrm{L}$. & R. Sales Junior, 2014 & $\begin{array}{l}\text { Brazil, Rio Grande } \\
\text { do Norte, Mossoró }\end{array}$ & $\begin{array}{l}4^{\circ} 52^{\prime} 53,4{ }^{\prime \prime} \mathrm{S} \\
37^{\circ} 26,20,25, \mathrm{~W}\end{array}$ & MG725333 & MG720056 & MG735250 & MG748819 & MG748778 \\
\hline M. semiaridus & CMM-4827 & T. portulacastrum $\mathrm{L}$. & R. Sales Junior, 2014 & $\begin{array}{l}\text { Brazil, Ceará, } \\
\text { Limoeiro do Norte }\end{array}$ & $\begin{array}{l}5^{\circ} 11^{\prime} 06,11^{\prime \prime} \mathrm{S} \\
37^{\circ} 55^{\prime} 2,2^{\prime \prime} \mathrm{W}\end{array}$ & MG725302 & MG720025 & MG735219 & MG748788 & MG748747 \\
\hline M. semiaridus & CMM-4828 & T. portulacastrum $\mathrm{L}$. & R. Sales Junior, 2014 & $\begin{array}{l}\text { Brazil, Ceará, } \\
\text { Limoeiro do Norte }\end{array}$ & $\begin{array}{l}5^{\circ} 11^{\prime} 06,11^{\prime \prime} \mathrm{S} \\
37^{\circ} 55^{\prime} 2,2^{\prime \prime} \mathrm{W}\end{array}$ & MG725303 & MG720026 & MG735220 & MG748789 & MG748748 \\
\hline M. semiaridus & CMM-4829 & T. portulacastrum $\mathrm{L}$. & R. Sales Junior, 2014 & $\begin{array}{l}\text { Brazil, Ceará, } \\
\text { Limoeiro do Norte }\end{array}$ & $\begin{array}{l}5^{\circ} 11^{\prime} 06,11^{\prime \prime} \mathrm{S} \\
37^{\circ} 55^{\prime} 2,2,{ }^{\prime \prime} \mathrm{W}\end{array}$ & MG725304 & MG720027 & MG735221 & MG748790 & MG748749 \\
\hline M. semiaridus & CMM-4830 & T. portulacastrum L. & R. Sales Junior, 2014 & $\begin{array}{l}\text { Brazil, Ceará, } \\
\text { Limoeiro do Norte }\end{array}$ & $\begin{array}{l}5^{\circ} 11^{\prime} 06,11^{\prime \prime} \mathrm{S} \\
37^{\circ} 55^{\prime} 2,2, \mathrm{~W}\end{array}$ & MG725305 & MG720028 & MG735222 & MG748791 & MG748750 \\
\hline M. semiaridus & CMM-4831 & T. portulacastrum $\mathrm{L}$. & R. Sales Junior, 2014 & $\begin{array}{l}\text { Brazil, Ceará, } \\
\text { Limoeiro do Norte }\end{array}$ & $\begin{array}{l}5^{\circ} 11^{\prime} 06,11^{\prime \prime} \mathrm{S} \\
37^{\circ} 55^{\prime} 2,2^{\prime \prime} \mathrm{W}\end{array}$ & MG725306 & MG720029 & MG735223 & MG748792 & MG748751 \\
\hline M. semiaridus & CMM-4859 & B. diffusa $\mathrm{L}$. & R. Sales Junior, 2014 & $\begin{array}{l}\text { Brazil, Rio Grande } \\
\text { do Norte, Mossoró }\end{array}$ & $\begin{array}{l}4^{\circ} 54^{\prime} 2^{\prime \prime} \mathrm{S} \\
37^{\circ} 24^{\prime} 17^{\prime \prime} \mathrm{W}\end{array}$ & MG725307 & MG720030 & MG735224 & MG748793 & MG748752 \\
\hline M. semiaridus & CMM-4860 & B. diffusa $\mathrm{L}$. & R. Sales Junior, 2014 & $\begin{array}{l}\text { Brazil, Rio Grande } \\
\text { do Norte, Mossoró }\end{array}$ & $\begin{array}{l}4^{\circ} 54^{\prime} 2^{\prime \prime} \mathrm{S} \\
37^{\circ} 24^{\prime} 17^{\prime \prime} \mathrm{W}\end{array}$ & MG725308 & MG720031 & MG735225 & MG748794 & MG748753 \\
\hline
\end{tabular}




\begin{tabular}{|c|c|c|c|c|c|c|c|c|c|c|}
\hline \multirow[t]{2}{*}{ Species } & \multirow[t]{2}{*}{ Strain number ${ }^{\mathrm{a}}$} & \multirow[t]{2}{*}{ Host } & \multirow{2}{*}{$\begin{array}{l}\text { Collected/isolated } \\
\text { by/year }\end{array}$} & \multirow[t]{2}{*}{ Location } & \multirow[t]{2}{*}{ Cordinates } & \multicolumn{5}{|c|}{ GenBank Accession Numbers. } \\
\hline & & & & & & $\overline{\mathrm{BT}}$ & $\overline{E F}$ & ITS & $\overline{\mathrm{LSU}}$ & $\overline{\text { SSU }}$ \\
\hline M. semiaridus & CMM-4861 & B. diffusa $\mathrm{L}$. & R. Sales Junior, 2014 & $\begin{array}{l}\text { Brazil, Rio Grande } \\
\text { do Norte, Mossoró }\end{array}$ & $\begin{array}{l}4^{\circ} 54^{\prime 2} 2^{\prime \prime} \mathrm{S} \\
37^{\circ} 24^{\prime} 17^{\prime} \mathrm{W}\end{array}$ & MG725309 & MG720032 & MG735226 & MG748795 & MG748754 \\
\hline Seynesia erumpens & SMH 1291 & - & - & - & & - & - & - & AF279410 & AF279409 \\
\hline
\end{tabular}

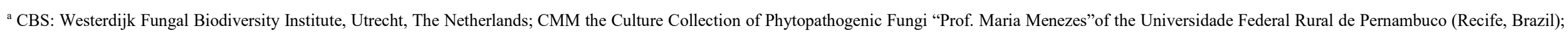

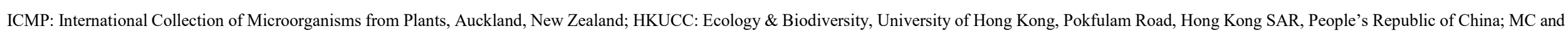

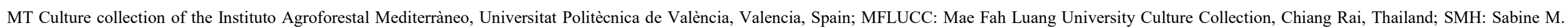
Huhndorf, Dept. of Botany, The Field Museum of Natural History, Chicago, USA.

Ex-type culture indicated in bold. 
Table 2 Temperature growth study of Monosporascus isolates.

\begin{tabular}{llll}
\hline Species name / strain number & \multicolumn{3}{c}{ Cardinal temperatures for growth $\left({ }^{\circ} \mathrm{C}\right)$} \\
& Minimum & Maximum & Optimum \\
\hline Monosporascus brasiliensis & & & \\
CMM 4839 & 10 & 45 & 32.1 \\
CMM 4843 & 10 & 45 & 31.7 \\
Monosporascus caatinguensis & & & \\
CMM 4833 & 10 & 45 & 30.7 \\
CMM 4835 & 10 & 45 & 31.2 \\
Monosporascus mossoroensis & & & \\
CMM 4857 & 10 & 45 & 31.8 \\
CMM 4858 & 10 & 45 & 31.1 \\
Monosporascus nordestinus & & & \\
CMM 4846 & 10 & 45 & 32.4 \\
CMM 4847 & 10 & 45 & 32.1 \\
Monosporascus semiaridus & & & \\
CMM 4830 & 10 & 45 & 31.3 \\
CMM 4859 & 10 & 45 & 32.9 \\
\hline
\end{tabular}


Table 3 Pairwise sequence percentage identity among Monosporascus species at the ITS, tefl- $\alpha, t u b$, LSU and SSU regions.

\begin{tabular}{|l|ll|l|l|l|l|}
\hline M. caatinguensis & 80.7 & 83.0 & 89.6 & 67.6 & 99.5 \\
\hline
\end{tabular}

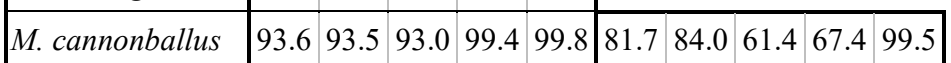

\begin{tabular}{|l|l|l|l|l|l|l|l|l|l|l|l|l|l|l|l|}
\hline M. eutypoides & 91.4 & 93.2 & 92.8 & 99.4 & 99.9 & 78.6 & 84.4 & 88.6 & 97.1 & 99.6 & 94.1 & 96.6 & 97.3 & 99.4 & 99.9 \\
\hline
\end{tabular}

\begin{tabular}{|l|l|l|l|l|l|l|l|l|l|l|l|l|l|l|l|l|l|l|l|l|}
\hline M. ibericus & 84.2 & 81.9 & 89.5 & 98.1 & 99.4 & 87.3 & 86.9 & 91.8 & 97.8 & 99.5 & 85.8 & 82.0 & 86.8 & 97.8 & 99.4 & 82.9 & 82.6 & 87.4 & 97.9 & 99.5 \\
\hline
\end{tabular}

\begin{tabular}{|l|l|l|l|l|l|l|l|l|l|l|l|l|l|l|l|l|l|l|l|l|l|l|l|l|l|}
\hline M. mossoroensis & 92.1 & 92.3 & 93.2 & 99.4 & 99.9 & 79.9 & 83.3 & 88.3 & 97.4 & 99.6 & 94.9 & 98.1 & 98.4 & 99.3 & 99.9 & 96.1 & 96.6 & 97.8 & 99.3 & 100 & 84.4 & 81.5 & 87.1 & 97.4 & 99.5 \\
\hline
\end{tabular}

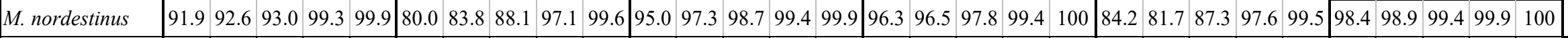

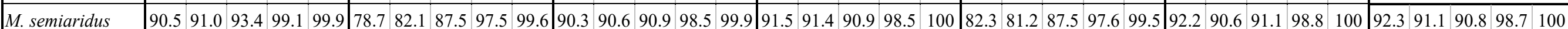

ITS tef tub LSU SSU ITS tef tub LSU SSU ITS tef tub LSU SSU ITS tef tub LSU SSU ITS tef tub LSU SSU ITS tef tub LSU SSU ITS tef tub LSU SSU

M. brasiliensis

M. caatinguensis

M. cannonballus

M. eutypoides

M. ibericus

M. mossoroensis

M. nordestinus 
Figure 1 Maximum likelihood phylogeny inferred from the combined LSU and SSU sequence alignments used to infer the phylogenetic relationships of the genus Monosporascus inside the family Diatrypaceae and the order Xylariales. Support values (ML bootstrap / MP bootstrap / BI posterior probabilities) are given at the nodes. Bootstrap values less than $70 \%$ or posterior probabilities less than 0.9 are indicated with “_“. The tree was rooted using Arecophila bambusae (HKUCC4794), Seynesia erumpens (SMH 1291), Arthrinium hysterinum (ICMP 6889), Ar. phaeospermum (HKUCC 3395) and Apiospora setosa (ICMP 4207) as outgroup sequences. Ex-type strains are indicated in bold. Scale bar shows expected changes per site. New species are indicated with an asterisk.

Figure 2 Maximum likelihood phylogeny inferred from the combined ITS, tefl- $\alpha$ and tub sequence alignments used to infer the relative position of species inside the Monosporascus genus. Support values (ML bootstrap / MP bootstrap / BI posterior probabilities) are given at the nodes. The tree was midpoint rooted. Ex-type strains are indicated in bold. Scale bar shows expected changes per site. New species are indicated with an asterisk.

Figure 3 Upper face of 30-days-old colonies of Monosporascus spp. grown on PDA culture medium at $25^{\circ} \mathrm{C}$ in darkness: A) M. brasiliensis CMM 4839; B) M. caatinguensis CMM 4833 and C) M. mossoroensis CMM 4857.

Figure 4 Monosporascus nordestinus CMM4846: A) Upper face of a 30-days-old colony grown on PDA culture medium at $25^{\circ} \mathrm{C}$ in darkness; B-D) Asci containing 1 (B), 2 (C) 
and 3 (D) mature ascospores; E) Ascus with 3 inmature ascospores; F) General view of asci and ascospores. Scale bars: B-F $=20 \mu \mathrm{m}$.

Figure 5 Monosporascus semiaridus CMM4830: A) Upper face of a 30-days-old colony grown on PDA culture medium at $25^{\circ} \mathrm{C}$ in darkness; B) Ascus containing 1 mature ascospore; C) Ascus containing 1 inmature ascospore. Scale bars: $B, C=20 \mu \mathrm{m}$. 


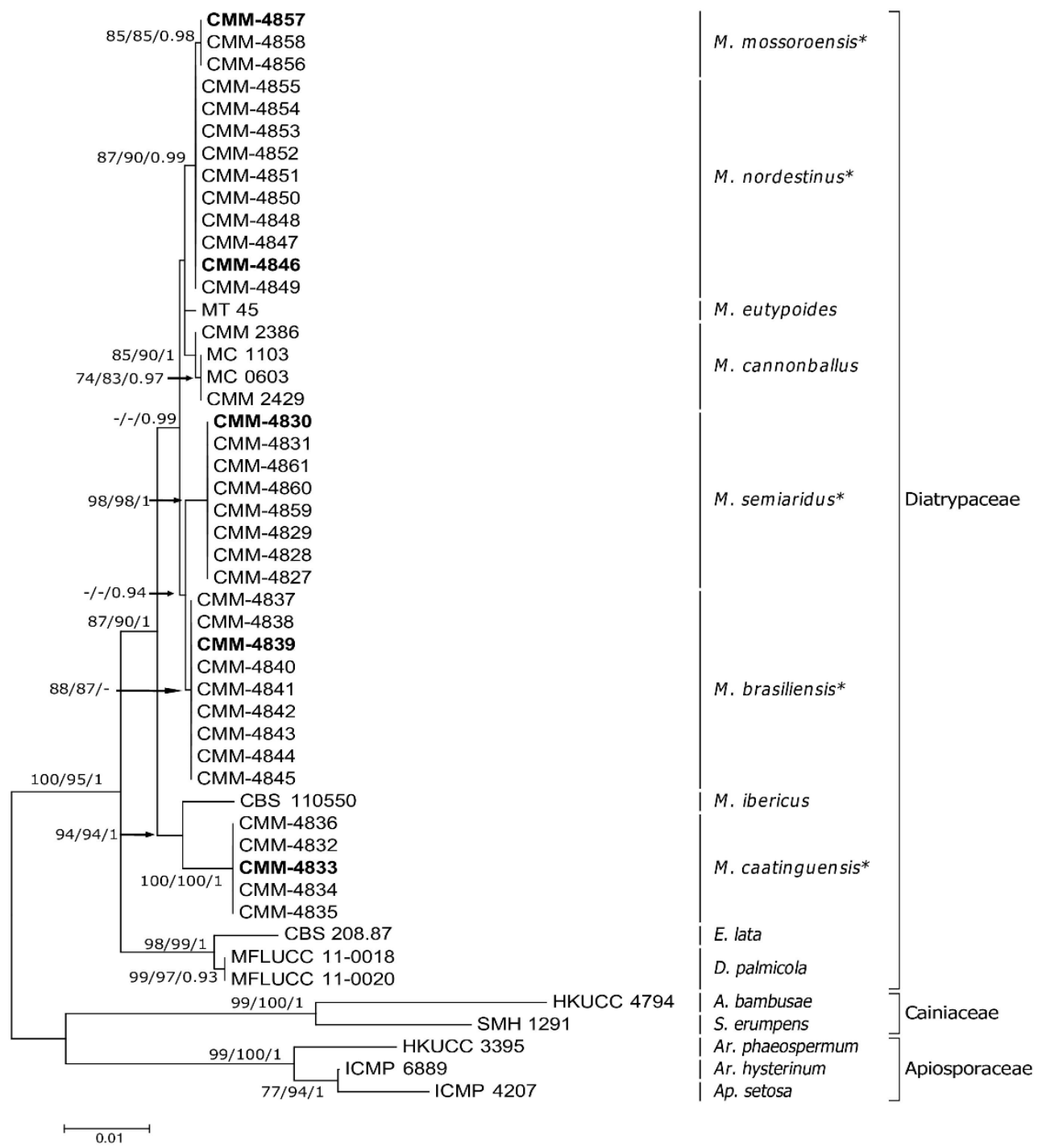

Figure 1 


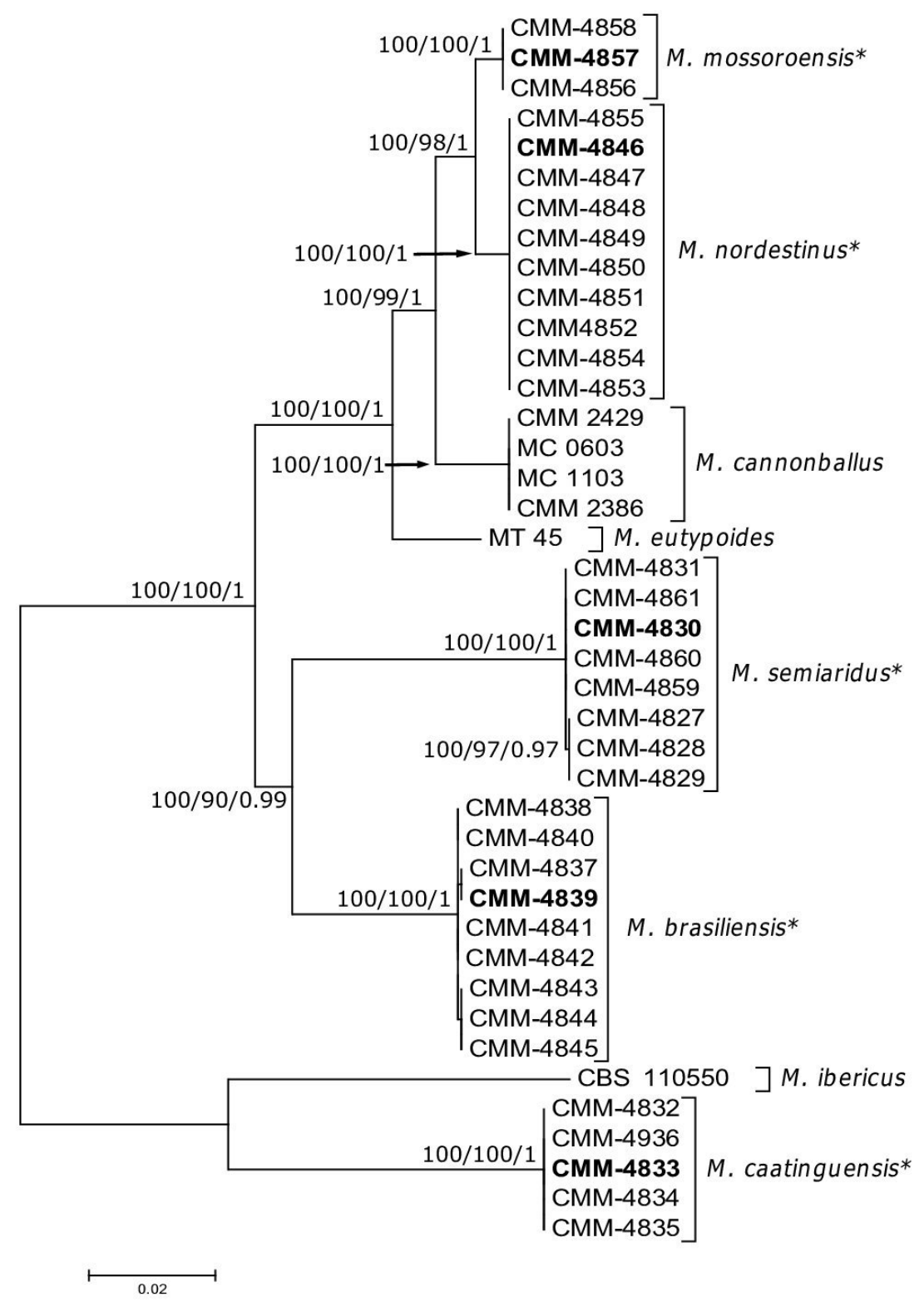

Figure 2 


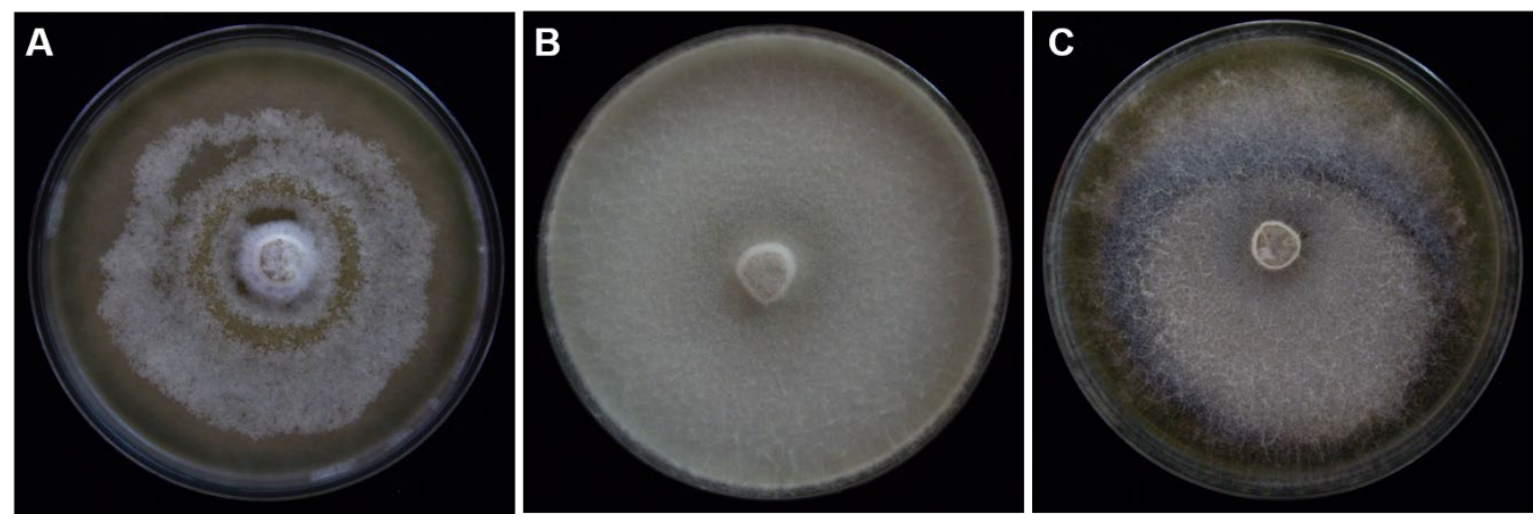

Figure 3 

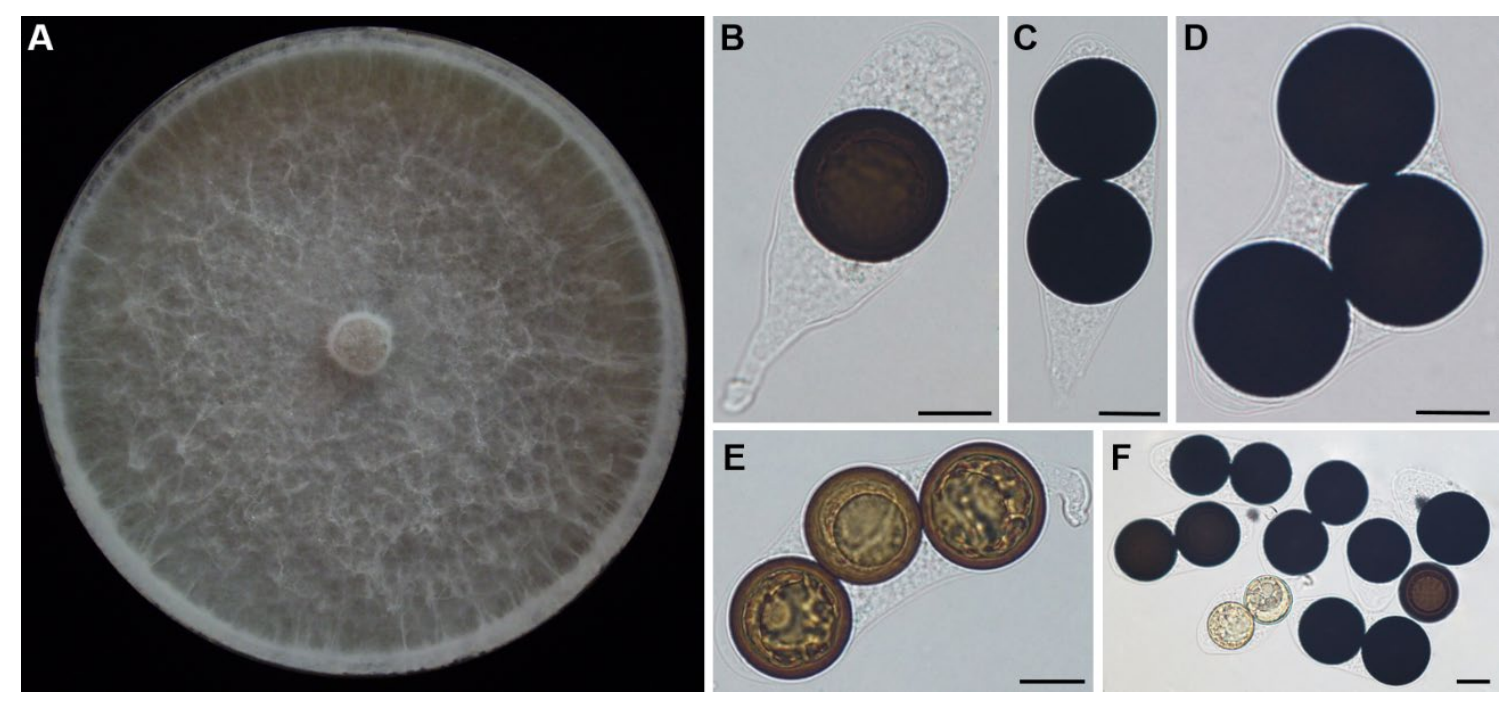

Figure 4 

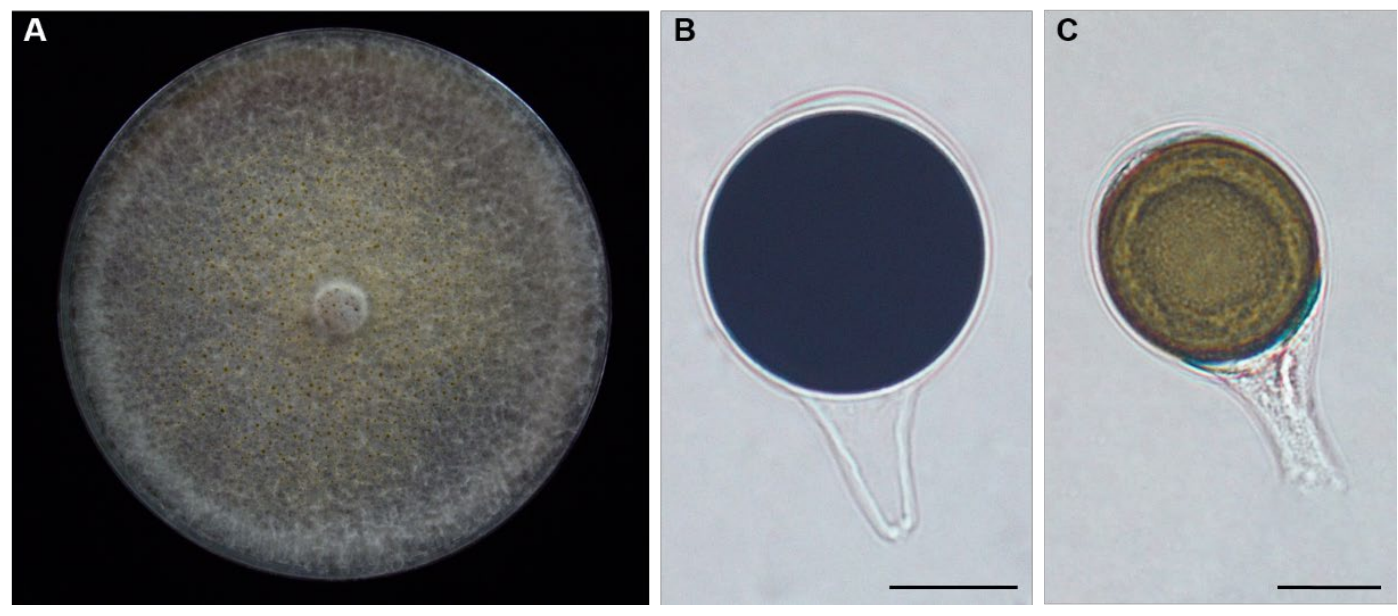

Figure 5 